\title{
Characterization of particulate organic matter in the Lena River delta and adjacent nearshore zone, NE Siberia - Part I: Radiocarbon inventories
}

\author{
M. Winterfeld ${ }^{1,2}$, T. Laepple ${ }^{3}$, and G. Mollenhauer ${ }^{1,2}$ \\ ${ }^{1}$ Alfred-Wegener-Institut, Helmholtz-Zentrum für Polar- und Meeresforschung, Am Handelshafen 12, \\ 25570 Bremerhaven, Germany \\ ${ }^{2}$ Department of Geosciences, University of Bremen, Klagenfurter Straße, 28359 Bremen, Germany \\ ${ }^{3}$ Alfred-Wegener-Institut, Helmholtz-Zentrum für Polar- und Meeresforschung, Telegrafenberg A43, \\ 14473 Potsdam, Germany
}

Correspondence to: M. Winterfeld (maria.winterfeld@awi.de)

Received: 9 August 2014 - Published in Biogeosciences Discuss.: 8 October 2014

Revised: 23 April 2015 - Accepted: 13 May 2015 - Published: 19 June 2015

\begin{abstract}
Particulate organic matter (POM) derived from permafrost soils and transported by the Lena River represents a quantitatively important terrestrial carbon pool exported to Laptev Sea sediments (next to POM derived from coastal erosion). Its fate in a future warming Arctic, i.e., its remobilization and remineralization after permafrost thawing as well as its transport pathways to and sequestration in marine sediments, is currently under debate. We present one of the first radiocarbon $\left({ }^{14} \mathrm{C}\right)$ data sets for surface water POM within the Lena Delta sampled in the summers of 2009-2010 and spring 2011 ( $n=30$ samples). The bulk $\Delta^{14} \mathrm{C}$ values varied from -55 to $-391 \%$ o translating into ${ }^{14} \mathrm{C}$ ages of 395 to 3920 years BP. We further estimated the fraction of soil-derived POM to our samples based on (1) particulate organic carbon to particulate nitrogen ratios (POC: $\mathrm{PN}$ ) and (2) on the stable carbon isotope $\left(\delta^{13} \mathrm{C}\right)$ composition of our samples. Assuming that this phytoplankton POM has a modern ${ }^{14} \mathrm{C}$ concentration, we inferred the ${ }^{14} \mathrm{C}$ concentrations of the soil-derived POM fractions. The results ranged from -322 to $-884 \%$ o (i.e., 3060 to $17250{ }^{14} \mathrm{C}$ years BP) for the POC: $\mathrm{PN}$-based scenario and from -261 to $-944 \%$ o (i.e., 2370 to 23100 ${ }^{14} \mathrm{C}$ years BP) for the $\delta^{13} \mathrm{C}$-based scenario. Despite the limitations of our approach, the estimated $\Delta^{14} \mathrm{C}$ values of the soil-derived POM fractions seem to reflect the heterogeneous ${ }^{14} \mathrm{C}$ concentrations of the Lena River catchment soils covering a range from Holocene to Pleistocene ages better than the bulk POM $\Delta{ }^{14} \mathrm{C}$ values. We further used a dual-carbonisotope three-end-member mixing model to distinguish be-
\end{abstract}

tween POM contributions from Holocene soils and Pleistocene Ice Complex (IC) deposits to our soil-derived POM fraction. IC contributions are comparatively low (mean of 0.14) compared to Holocene soils (mean of 0.32) and riverine phytoplankton (mean of 0.55 ), which could be explained with the restricted spatial distribution of IC deposits within the Lena catchment. Based on our newly calculated soilderived POM $\Delta^{14} \mathrm{C}$ values, we propose an isotopic range for the riverine soil-derived POM end member with $\Delta^{14} \mathrm{C}$ of $-495 \pm 153 \%$ o deduced from our $\delta^{13} \mathrm{C}$-based binary mixing model and $\delta^{13} \mathrm{C}$ of $-26.6 \pm 1 \%$ deduced from our data of Lena Delta soils and literature values. These estimates can help to improve the dual-carbon-isotope simulations used to quantify contributions from riverine soil POM, Pleistocene IC POM from coastal erosion, and marine POM in Siberian shelf sediments.

\section{Introduction}

Huge amounts of soil organic carbon are currently stored frozen in permafrost soils of the high northern latitudes (e.g., Tarnocai et al., 2009; Zimov et al., 2009) and excluded from biogeochemical cycling. Due to recent observed and projected amplified warming of the Arctic (ACIA, 2005; Serreze et al., 2000), carbon cycling and the fate of organic carbon released from permafrost soils have received growing attention 
(e.g., Guo et al., 2007; McGuire et al., 2009; Schuur et al., 2008, 2009; Zimov et al., 2006).

Increasing permafrost temperatures, increasing thaw depth in summer (active layer depth), increasing river runoff (Boike et al., 2013; McClelland et al., 2012; Peterson et al., 2002), and increasing length of the open water season (Markus et al., 2009) affecting coastal erosion of permafrost deposits will likely lead to enhanced mobilization and export of old, previously frozen organic matter $(\mathrm{OM})$ to the Arctic shelf seas. The understanding of the different terrestrial OM sources (e.g., fresh vegetation, surface soils, Pleistocene Ice Complex (IC)) and their age and quality has significantly improved over the last decade (e.g., Guo et al., 2007; Vonk et al., 2010). The use of carbon isotopes $\left(\delta^{13} \mathrm{C}, \Delta^{14} \mathrm{C}\right)$ of dissolved and particulate organic matter as well as individual biomarkers has helped characterizing and distinguishing these different carbon pools, e.g., old, yet little degraded Pleistocene IC-derived OM and comparatively younger and more degraded fluvial OM reaching the Siberian shelf seas (Feng et al., 2013; Guo et al., 2004; Gustafsson et al., 2011; Karlsson et al., 2011; Vonk et al., 2012, 2010).

However, particularly in Siberia, ${ }^{14} \mathrm{C}$ data on riverine suspended particulate organic matter (POM) are only sparsely available. A recently published data set from the Arctic Great Rivers Observatory (A-GRO, www.arcticgreatrivers. org, published 10 January 2015) provides POM ${ }^{14} \mathrm{C}$ data for the Lena River from Zhigansk, approximately $900 \mathrm{~km}$ upstream of the delta. To our knowledge the only additional $\mathrm{POM}{ }^{14} \mathrm{C}$ concentrations sampled directly in Siberian rivers are from the Lena River (unpublished in Vonk et al., 2010) and the Kolyma River (Supplement of Vonk et al., 2012). Available POM ${ }^{14} \mathrm{C}$ concentrations for Siberia are from offshore of the deltas of the Lena (Karlsson et al., 2011) and Kolyma rivers (Vonk et al., 2010) and inferred from a sediment core taken in a floodplain lake of the Ob' River (Dickens et al., 2011). Due to settling of POM and marine primary production fueled by the riverine nutrients, the ${ }^{14} \mathrm{C}$ concentrations of samples taken off the river mouths are already altered from the "original" river signal. In contrast to Siberia, there are detailed studies on riverine POM ${ }^{14} \mathrm{C}$ concentrations in the Yukon and Mackenzie rivers in the North American Arctic (Goñi et al., 2005; Guo et al., 2007; Guo and Macdonald, 2006). Here, the POM was found to be significantly older than the dissolved organic matter (DOM) of these rivers and interpreted to be derived from riverbank erosion and thawing permafrost soils compared to a modern vegetation source of DOM (Guo et al., 2006, 2007). Against the backdrop of a warming Arctic (IPCC, 2013; ACIA, 2005) and the projected release of old OM in the future presumably as POM rather than DOM (Guo et al., 2007), it is important to assess the age heterogeneity carried by riverine POM and sequestered in the nearshore zone today. This will be an important benchmark to distinguish catchment-related changes caused by increasing temperatures from the natural variability of the river system.
In contrast to sedimentary OM, POM provides limited spatial and temporal snapshots of its OM properties. However, it has been shown that riverine POM in Arctic rivers carries an integrated signal from their permafrost watersheds representing the watershed environmental characteristics (e.g., Goñi et al., 2000; Lobbes et al., 2000; Vonk and Gustafsson, 2009; Winterfeld et al., 2015). Despite the fact that Lena River POM flux is an order of magnitude smaller than its DOM flux, it is more likely to transports the climate change signal from permafrost soils of the river catchment (Guo et al., 2007). Also, it has been proposed that the POM pool could be as important as the DOM pool for Arctic carbon cycling, because of its possibly high degradation rates in the water column compared to DOM (Sanchéz-García et al., 2011; van Dongen et al., 2008).

Here we present the first part of a study on particulate OM in the Lena Delta, Siberia (Winterfeld et al., 2015). Our POM samples taken in three consecutive years (2009-2011) in the spring and summer seasons add up to the existing data on elemental composition, stable carbon isotopes $\left(\delta^{13} \mathrm{C}\right)$, and radiocarbon $\left({ }^{14} \mathrm{C}\right)$ values as well as provide a first POM ${ }^{14} \mathrm{C}$ data set covering three consecutive years in the Lena Delta. Because riverine and marine POM concentrations are usually too low for source specific biomarker ${ }^{14} \mathrm{C}$ analysis, the available ${ }^{14} \mathrm{C}$ data are from bulk OM. This could result in a considerable age bias depending on the contribution of phytoplankton OM with a rather enriched (modern) ${ }^{14} \mathrm{C}$ concentration to the individual samples. We used different approaches to estimate the fraction of soil- and plankton-derived OM in our POM samples and estimated the ${ }^{14} \mathrm{C}$ concentration for the soil-derived fraction of POM transported by the Lena River in summer and spring. Further, we used a dual-carbonisotope three-end-member mixing model according to Vonk et al. $(2010,2012)$ to distinguish not only between planktonand soil-derived OM but also between OM from Holocene soils and Pleistocene IC deposits. The estimated ${ }^{14} \mathrm{C}$ concentrations of soil-derived POM will further help to define the typical isotopic signature of river POM more accurately for modeling riverine OM contributions to Laptev Sea shelf sediments.

\section{Material and methods}

\subsection{Study area}

A detailed description of the Lena River watershed and Lena Delta can, for example, be found in the companion paper of this study, which deals with the lignin composition of OM in the Lena Delta (Winterfeld et al., 2015).

In short, the Lena River is one of the largest Russian Arctic rivers, draining a watershed of $\sim 2.46 \times 10^{6} \mathrm{~km}^{2}$ in central Siberia into the Laptev Sea. Continuous permafrost makes up about $72-80 \%$ of the drainage area (Amon et al., 2012; Zhang et al., 2005), storing huge amounts of old OM. The 


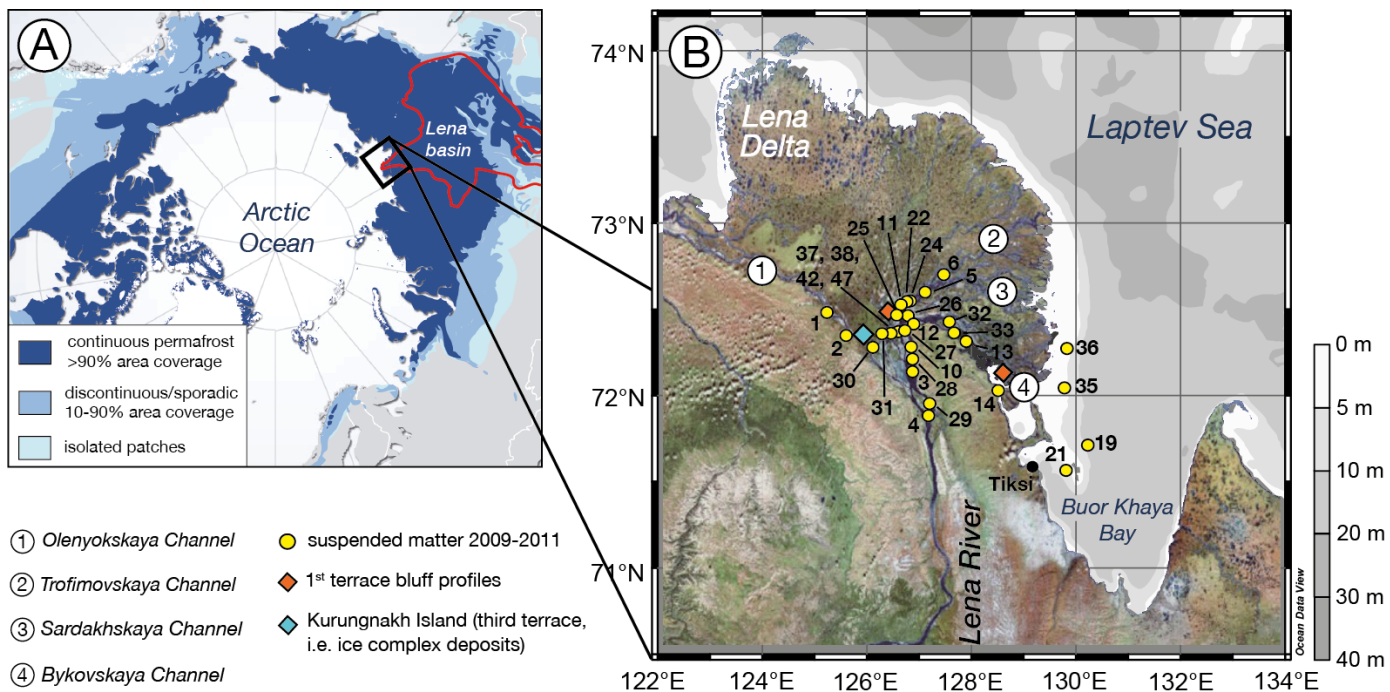

Figure 1. (a) Lena River catchment area within the Northern Hemisphere permafrost zone (map by Hugo Ahlenius, UNEP/GRID-Arendal; see www.grida.no/graphicslib/detail/permafrost-extent-in-the-northern-hemisphere_1266; source data from Brown et al., 1998). (b) Lena Delta and Buor Khaya Bay sampling sites from 2009 to 2011 analyzed for radiocarbon content (see also Table 1).

permafrost acts as a water impermeable layer and thus affects the regional hydrology and hydrochemistry. The Lena River water discharge and related dissolved and particulate load discharge are highest during spring ice breakup and snowmelt in late May to June, while summer and winter discharges are lower (Rachold et al., 2004). The mean annual water discharge is $\sim 588 \mathrm{~km}^{3}$ for the years 1999 to 2008 (Holmes et al., 2012). Corresponding annual sediment, dissolved organic carbon (DOC), and particulate organic carbon (POC) fluxes are 20.7 (Holmes et al., 2002), 5.7 (Holmes et al., 2012), and $1.2 \mathrm{Tg} \mathrm{yr}^{-1}$, respectively (Rachold and Hubberten, 1999). A second major source for terrigenous OM delivered to the Laptev Sea is the thermal erosion of iceand OM-rich Pleistocene IC deposits along the coast (see Gustafsson et al., 2011; Mueller-Lupp et al., 2000; Rachold and Hubberten, 1999; Rachold et al., 2004). Recently, it has been shown that the annual supply of total organic carbon from IC deposits along the Laptev Sea coast by erosion is $\sim 0.66 \mathrm{Tg} \mathrm{yr}^{-1}$ (Günther et al., 2013).

The Lena River Delta is the largest Arctic delta $\left(\sim 32000 \mathrm{~km}^{2}\right)$. It is characterized by a polygonal tundra landscape with active floodplains, and it can be divided into three geomorphological terraces (Grigoriev, 1993; Schwamborn et al., 2002). The first terrace includes active floodplains that were formed during the Holocene and makes up about $55 \%$ of the total delta area (Morgenstern et al., 2008), covering the central and eastern part. Within the first delta terrace remains of a Pleistocene accumulation plain, also called Ice Complex or yedoma deposits, form the third terrace, covering about $6 \%$ of the total delta area (Morgenstern et al., 2008). Sandy islands forming the second terrace cover the rest of the delta in the west. Water and sed- iment discharge are not equally distributed through the several delta channels. Approximately $80-90 \%$ of the total water and up to $85 \%$ of the sediment discharge are delivered through the three main eastern channels to the Buor Khaya Bay east of the delta (Fig. 1b), i.e., through the SardakhskoTrofimovskaya channel system (60-75\% water, $70 \%$ sediment) and the Bykovskaya Channel (20-25 water, $15 \%$ sediment). Only a minor portion is discharged to the north and west through the Tumatskaya and Olenyokskaya channels (5-10 water, $10 \%$ sediment) (Charkin et al., 2011, and references therein; Ivanov and Piskun, 1999).

\subsection{Sampling}

The sampling sites presented in this study are located in the eastern part of the Lena Delta and adjacent Buor Khaya Bay (Table 1, Fig. 1b) in and along the channels of highest discharge. Permafrost soil samples from the first delta and surface water total suspended matter (TSM) were collected during three expeditions in August 2009, July/August 2010, and in late May and late June/early July 2011. All soil samples were taken from riverbank bluffs of the first delta terrace (Holocene formation), which is elevated $(5-16 \mathrm{~m})$ over the active floodplains. The soil profiles vary strongly in sediment composition and OM content. Within the profiles, sandy layers derived from extreme flooding events (Schwamborn et al., 2002) and aeolian input (Kutzbach et al., 2004; Sanders, 2011) alternate with buried surface soil layers and peat layers rich in fibrous plant and root detritus in different stages of decomposition. The peat layers are either of autochthonous or of allochthonous origin. Allochthonous material is eroded from riverbanks further upstream and redeposited in the delta. In order to obtain samples that reflect the original state 
Table 1. Soil samples from riverbank bluffs and total suspended matter (TSM) samples presented in this study analyzed for particulate organic carbon as well as stable and radiocarbon isotope composition. Latitude and longitude are given in decimal degrees $\left(^{\circ}\right)$. Bluff height is given in meters above river level (m a.r.l.) measured in August 2009 and only applicable for the soil samples. The TSM samples were taken from the surface water layer at a sampling depth of ca. $0.5 \mathrm{~m}$.

\begin{tabular}{|c|c|c|c|c|c|}
\hline $\begin{array}{l}\text { Sample } \\
\text { code }\end{array}$ & $\begin{array}{l}\text { Sample and site } \\
\text { description }\end{array}$ & $\begin{array}{l}\text { Date of } \\
\text { sampling }\end{array}$ & $\begin{array}{l}\text { Lat. } \mathrm{N} \\
\left({ }^{\circ}\right)\end{array}$ & $\begin{array}{l}\text { Long. E } \\
\left(^{\circ}\right)\end{array}$ & $\begin{array}{l}\text { Bluff height } \\
\text { (m a.r.l.) }\end{array}$ \\
\hline \multicolumn{6}{|c|}{ Lena Delta first terrace soil profiles } \\
\hline L09-12 & Samoylov Island, 5 depths sampled & 18 Aug 2009 & 72.3775 & 126.4954 & 7.5 \\
\hline L09-28-2 & Bykovskaya Channel, 2 depths sampled & 21 Aug 2009 & 72.0586 & 128.6309 & 1.7 \\
\hline \multicolumn{6}{|c|}{ Lena Delta TSM } \\
\hline 1 & Olenyokskaya Channel & 14 Aug 2009 & 72.4772 & 125.2856 & \\
\hline 2 & Olenyokskaya Channel & 14 Aug 2009 & 72.3598 & 125.6728 & \\
\hline 3 & Lena River main channel & 16 Aug 2009 & 72.1526 & 126.9160 & \\
\hline 4 & Lena River main channel south of Tit Ari Island & 16 Aug 2009 & 71.9040 & 127.2544 & \\
\hline 5 & Sardakhskaya-Trofimovskaya Channel & 17 Aug 2009 & 72.5825 & 127.1891 & \\
\hline 6 & Sardakhskaya Channel & 17 Aug 2009 & 72.7002 & 127.4930 & \\
\hline 7 & Sardakhskaya-Trofimovskaya Channel & 17 Aug 2009 & 72.6268 & 127.3860 & \\
\hline 8 & Near Kurungnakh Island & 18 Aug 2009 & 72.2904 & 126.0909 & \\
\hline 9 & Lena River main channel & 19 Aug 2009 & 72.2987 & 126.7080 & \\
\hline 10 & Lena River main channel & 19 Aug 2009 & 72.2760 & 126.9041 & \\
\hline 11 & Lena River main channel & 19 Aug 2009 & 72.5159 & 126.7142 & \\
\hline 12 & Bykovskaya Channel & 20 Aug 2009 & 72.4140 & 126.9124 & \\
\hline 13 & Lena River Bykovskaya Channel & 20 Aug 2009 & 72.2352 & 127.9619 & \\
\hline 14 & Lena River Bykovskaya Channel & 20 Aug 2009 & 72.0341 & 128.5232 & \\
\hline 15 & Lena River Bykovskaya Channel & 21 Aug 2009 & 72.0354 & 128.0974 & \\
\hline 16 & Lena River Bykovskaya Channel & 21 Aug 2009 & 72.0586 & 128.6309 & \\
\hline 17 & Offshore of Bykovsky Peninsula & 22 Aug 2010 & 71.7889 & 129.4189 & \\
\hline 18 & NE of Muostakh Island & 22 Aug 2010 & 71.6761 & 130.1728 & \\
\hline 19 & NE of Muostakh Island & 22 Aug 2010 & 71.7062 & 130.2900 & \\
\hline 20 & W of Muostakh Island & 23 Aug 2010 & 71.6088 & 129.9393 & \\
\hline 21 & Close to Muostakh Island shoreline & 23 Aug 2010 & 71.5750 & 129.8200 & \\
\hline 22 & Close to Samoylov Island & 30 Jul 2010 & 72.3650 & 126.4628 & \\
\hline 24 & Sardakhskaya-Trofimovskaya Channel & 31 Jul 2010 & 72.5343 & 126.8794 & \\
\hline 25 & Lena River Trofimovskaya Channel & 31 Jul 2010 & 72.4764 & 126.6250 & \\
\hline 26 & Lena River Trofimovskaya Channel & 31 Jul 2010 & 72.4764 & 126.8588 & \\
\hline 27 & Lena River main channel south of Samoylov & 1 Aug 2010 & 72.3776 & 126.7478 & \\
\hline 28 & Lena River main channel north of Tit Ari Island & 1 Aug 2010 & 72.2102 & 126.9423 & \\
\hline 29 & Lena River main channel south of Tit Ari Island & 1 Aug 2010 & 71.9514 & 127.2582 & \\
\hline 30 & Lena River main channel off Kurungnakh & 2 Aug 2010 & 72.2808 & 126.2091 & \\
\hline 31 & Lena River main channel & 2 Aug 2010 & 72.3567 & 126.3521 & \\
\hline 32 & Lena River Bykovskaya Channel & 3 Aug 2010 & 72.3604 & 127.6761 & \\
\hline 33 & Bykovskaya Channel & 3 Aug 2010 & 72.3604 & 127.6765 & \\
\hline 34 & Off Bykovsky Peninsula & 4 Aug 2010 & 71.7015 & 129.7523 & \\
\hline 35 & Offshore of Lena Delta & 6 Aug 2010 & 72.0379 & 129.7694 & \\
\hline 36 & Offshore of Lena Delta & 6 Aug 2010 & 72.2753 & 129.8248 & \\
\hline 37 & Lena River main channel off Samoylov Island & 29 May 2011 & 72.3651 & 126.4757 & \\
\hline 38 & Lena River main channel, south of Stolb & 26 Jun 2011 & 72.3705 & 126.6538 & \\
\hline 39 & Off Kurungnakh & 26 Jun 2011 & 72.3334 & 126.2914 & \\
\hline 40 & Close to Samoylov Island & 29 Jun 2011 & 72.3681 & 126.4738 & \\
\hline 41 & Close to Samoylov Island & 29 Jun 2011 & 72.3681 & 126.4738 & \\
\hline 42 & Close to Samoylov Island & 30 Jun 2011 & 72.3681 & 126.4738 & \\
\hline 43 & Close to Samoylov Island & 30 Jun 2011 & 72.3681 & 126.4738 & \\
\hline 44 & Close to Samoylov Island & 1 Jul 2011 & 72.3681 & 126.4738 & \\
\hline 45 & Close to Samoylov Island & 1 Jul 2011 & 72.3681 & 126.4738 & \\
\hline 46 & Close to Samoylov Island & 2 Jul 2011 & 72.3681 & 126.4738 & \\
\hline 47 & Close to Samoylov Island & 2 Jul 2011 & 72.3681 & 126.4738 & \\
\hline
\end{tabular}


of the frozen permafrost soils, we removed the thawed soil material from each riverbank bluff for its total height with a spade. Frozen pieces of soil were then excavated at different depths using a hatchet and a hammer.

Suspended particulate matter of Lena River surface water was sampled at different stations in the main river channels of the delta on the Russian vessel Puteyski 405 (Fig. 1b, Table 1) from the upper $0.5 \mathrm{~m}$ of the water column. In the smaller delta channels the samples were taken approximately in the middle of the channel. Because the main delta channels can be $>1 \mathrm{~km}$ in width, we sampled a few hundred meters off the shore with water depth of $>10 \mathrm{~m}$, but not in the middle of the channel. Three samples $(19,35,36$; Fig. 1b) were taken outside the delta in shallow water depth. We discuss these samples as "delta samples", because the surface water at these sampling locations is outflowing Lena River water as shown by temperature and salinity profiles by Semiletov et al. (2011) and Kraberg et al. (2013). Between 1 and $30 \mathrm{~L}$ of water was filtered on pre-combusted $\left(4.5 \mathrm{~h}\right.$ at $\left.450^{\circ} \mathrm{C}\right)$ and pre-weighed glass fiber filters (GF / F Whatman, $0.7 \mu \mathrm{m}$ membrane) for particulate organic carbon (POC) and nitrogen $(\mathrm{PN})$ analysis as well as carbon isotope analysis. Additionally, one water sample of $20 \mathrm{~L}$ from the spring freshet in 2011 was stored cooled in opaque canisters for several days to allow for the suspended matter to settle. Before the supernatant water was decanted, it was filtered on pre-combusted and pre-weighed GF / F filters to check for the TSM remaining in suspension. For this sample (sample ID 37) the SPM of the supernatant water represented $0.1 \%$ of the settled material on a dry weight basis, and therefore the loss of material in suspension can be neglected.

The soil samples were stored in pre-combusted glass jars $\left(4.5 \mathrm{~h}\right.$ at $\left.450^{\circ} \mathrm{C}\right)$ and $\mathrm{GF} / \mathrm{F}$ filters were either stored in pre-combusted Petri dishes $(\varnothing 47 \mathrm{~mm})$ or wrapped in precombusted aluminum foil. All samples were kept frozen at $-20^{\circ} \mathrm{C}$ during storage and transport until analysis.

\subsection{Laboratory analyses}

Soil and sediment samples were freeze-dried, homogenized, and subsampled for elemental analysis. All filters were ovendried at $40^{\circ} \mathrm{C}$ for $24 \mathrm{~h}$.

\subsubsection{Elemental analyses}

Weight percent organic carbon (OC) and total nitrogen (TN) content of soil samples were determined by high-temperature combustion after removal of carbonates as described by Goñi et al. (2003). TSM samples were analyzed for OC and TN at the Alfred Wegener Institute in Bremerhaven, Germany, using the same protocol. Every 10 samples, control standards were analyzed to constrain the analytical uncertainty of $0.1 \%$.

\subsubsection{Carbon isotope analysis $\left(\Delta^{14} \mathrm{C}, \delta^{13} \mathrm{C}\right)$}

Samples were radiocarbon-dated at the National Ocean Sciences Accelerator Mass Spectrometry (NOSAMS) facility at Woods Hole Oceanographic Institution, USA. Bulk sediment samples and filters with TSM were submitted unprocessed, and inorganic carbon was removed during sample preparation at NOSAMS. The radiocarbon analyses at NOSAMS were carried out using standard methods (McNichol et al., 1994). Results are reported as $\Delta^{14} \mathrm{C}$, conventional radiocarbon ages (years $\mathrm{BP})$, and fraction modern carbon $(f \mathrm{MC})$ including the correction for isotope fractionation (Stuiver and Polach, 1977).

The stable carbon isotope composition $\left(\delta^{13} \mathrm{C}\right)$ was measured on splits of the $\mathrm{CO}_{2}$ gas of the samples generated prior to graphite reduction at NOSAMS using a VG Optima IRMS. Results are reported in per mil (\%o) relative to VPDB.

\subsection{End-member modeling}

The relative source contributions (phytoplankton and soil) to the POM samples are estimated by solving linear twoend-member (using $\mathrm{POC}: \mathrm{PN}$ and $\delta^{13} \mathrm{C}$ as parameters) and dual-carbon-isotope $\left({ }^{13} \mathrm{C}, \Delta{ }^{14} \mathrm{C}\right)$ three-end-member mixing models with end members determined from own data and the literature. The end-member values used in the different modeling approaches are given in Table 4. Source data for the calculation of the POC:PN soil end member as well as the ${ }^{13} \mathrm{C}$ and $\Delta^{14} \mathrm{C}$ end members for Holocene soil are given in Tables S1-S3 in the Supplement.

To account for the uncertainty of the measured values, we assume independent, normally distributed uncertainties for the observed values with a standard deviation characterizing the measurement uncertainty. For the end members we assume a normal distribution using the standard deviations from the observed samples on which the end members are based.

Uncertainty in the resulting contributions of phytoplankton and soil are estimated in a Monte Carlo approach similar to Vonk et al. $(2010,2012)$ and Karlsson et al. (2011). The source fractions are estimated 100000 times, each time drawing the end members as well as the observed values from their distributions. Solutions with negative fractions are omitted and the mean and the standard deviation are reported.

\section{Results}

\subsection{Elemental composition}

The organic carbon (OC) and total nitrogen (TN) concentrations of the first terrace soil samples can be found in Tables 3 and S3 in the companion paper, Winterfeld et al. (2015).

The surface water POC concentrations within the delta showed a high spatial and interannual variability, similar to the TSM concentrations of the respective sam- 
Table 2. Particulate organic carbon (POC) contents in Lena Delta surface water (2009 to 2011) given in milligrams per liter (mg $\mathrm{L}^{-1}$ ) and percent based on sediment dry weight (wt \%) as well as atomic particulate organic carbon (POC) to particulate total nitrogen (PN) ratios. Data on individual samples can be found in the Supplement (Table S4). Note that for August 2009 there are only $n=20$ samples for POC (wt \%), because the total suspended matter concentration was not determined for sample 19.

\begin{tabular}{|c|c|c|c|c|}
\hline & & $\begin{array}{c}\mathrm{POC} \\
\left(\mathrm{mgL}^{-1}\right)\end{array}$ & $\begin{array}{l}\text { POC } \\
(\mathrm{wt} \%)\end{array}$ & $\begin{array}{c}\text { Atomic } \\
\text { POC }: \text { PN }\end{array}$ \\
\hline \multirow[t]{5}{*}{ Lena Delta Aug 2009} & & $n=21$ & $n=20$ & $n=21$ \\
\hline & mean & 1.21 & 7.2 & 9.6 \\
\hline & median & 0.83 & 4.7 & 9.2 \\
\hline & $\min$ & 0.35 & 1.9 & 6.8 \\
\hline & $\max$ & 7.24 & 37.7 & 19.3 \\
\hline \multirow[t]{5}{*}{ Lena Delta Jul/Aug 2010} & & $n=13$ & $n=13$ & $n=13$ \\
\hline & mean & 0.57 & 3.05 & 7.6 \\
\hline & median & 0.47 & 3.25 & 3.05 \\
\hline & $\min$ & 0.15 & 1.42 & 3.7 \\
\hline & $\max$ & 1.30 & 4.74 & 10.3 \\
\hline $\begin{array}{l}\text { Lena Delta late May } 2011 \\
\text { sample code: } 37\end{array}$ & & 8.20 & 1.66 & 7.5 \\
\hline \multirow[t]{5}{*}{ Lena Delta late Jun/early Jul 2011} & & $n=9$ & $n=9$ & $n=9$ \\
\hline & mean & 0.74 & 4.32 & 7.8 \\
\hline & median & 0.69 & 4.61 & 7.8 \\
\hline & $\min$ & 0.29 & 3.20 & 5.9 \\
\hline & $\max$ & 1.51 & 4.99 & 9.7 \\
\hline
\end{tabular}

ples. The mean POC concentration for August 2009 was $1.21 \mathrm{mg} \mathrm{L}^{-1}\left(n=21\right.$, range $\left.0.35-7.24 \mathrm{mg} \mathrm{L}^{-1}\right)$ and corresponding POC content was $7.2 \mathrm{wt} \%$ (range $1.9-37.7 \mathrm{wt} \%$, Tables 2 and S1). The POC contents for July/August 2010 and June/July 2011 were lower than in 2009 with mean concentrations of $0.57 \mathrm{mg} \mathrm{L}^{-1}\left(n=13,0.15-1.30 \mathrm{mg} \mathrm{L}^{-1}\right)$ and $3.1 \mathrm{wt} \%(1.4-4.7 \mathrm{wt} \%)$ as well as $0.74 \mathrm{mg} \mathrm{L}^{-1}(n=$ $\left.9,0.29-1.51 \mathrm{mg} \mathrm{L}^{-1}\right)$ and $4.3 \mathrm{wt} \%(3.2-5.0 \mathrm{wt} \%)$, respectively. The single sample from late May 2011 (sample ID 37) showed highest POC concentration per liter $\left(8.2 \mathrm{mg} \mathrm{L}^{-1}\right)$ of all presented samples with a related POC content of $1.7 \mathrm{wt} \%$. Our POC data are well within the range of values reported for the Lena Delta before (Cauwet and Sidorov, 1996; Rachold and Hubberten, 1999; Semiletov et al., 2011). The two samples from the Buor Khaya Bay surface waters showed the lowest POC concentrations per liter, i.e., $0.37 \mathrm{mg} \mathrm{L}^{-1}$ (sample 35) and $0.15 \mathrm{mg} \mathrm{L}^{-1}$ (sample 36) with corresponding 4.4 and $1.5 \mathrm{wt} \%$ POC, respectively (Tables 2 and S4). The considerable drop of POC (and TSM) concentrations offshore of the delta is due to flocculation and settling of TSM in the zone of fresh and salt water mixing (e.g., Lisitsyn, 1995) and was also observed during other years of sampling (e.g., Cauwet and Sidorov, 1996; Semiletov et al., 2011).

The atomic particulate organic carbon (POC) to particulate nitrogen $(\mathrm{PN})$ ratios $(\mathrm{POC}: \mathrm{PN})$ of samples taken in summer 2009 were slightly higher than for summer 2010 samples, with mean values of $9.6(n=20,6.8-19.3)$ and $8.0(n=13$, 5.0-10.3, Tables 2 and S4), respectively. The POC: PN ra- tios of samples taken in June/July 2011 were rather similar to the July/August samples with a mean of $7.8(n=9,5.9-9.7)$. The sample from late May 2011 had a POC: PN ratio of 7.5.

\subsection{Carbon isotope inventories}

The stable carbon $\left(\delta^{13} \mathrm{C}\right)$ and radiocarbon $\left({ }^{14} \mathrm{C}\right)$ results are shown in Table 3. The radiocarbon data presented here will predominantly be discussed in terms of $\Delta^{14} \mathrm{C}$ in per mil $(\% o)$. Additionally, the fraction modern carbon (fMC) and ${ }^{14} \mathrm{C}$ ages in years before present (years BP) are given in Table 3.

\subsubsection{Stable carbon isotope composition $\left(\delta^{13} \mathrm{C}\right)$}

The two soil profiles from the first delta terrace showed $\delta^{13} \mathrm{C}$ values between -27.0 and $-25.1 \%$ with a mean of $-26.1 \%$ o, $(n=7$, Table 3$)$, which is within the range observed for Holocene soils in the delta (e.g., Schirrmeister et al., 2011, and references therein). Similar to the POC contents, the Lena Delta surface water POM $\delta^{13} \mathrm{C}$ values varied strongly spatially and annually (Fig. S1 in the Supplement). POM from August 2009 showed more depleted $\delta^{13} \mathrm{C}$ values compared to the other years, ranging from -34.2 to $-28.8 \%$ o (mean value $=-30.4 \%, n=13$ ). July/August 2010 and June/July 2011 POM isotopic compositions ranged from -30.4 to $-28.3 \%$ o (mean value $=-29.3 \%, n=13$ ) and from -29.3 to $-28.3 \%$ (mean value $=-28.7 \%$ o, $n=3$ ), respectively. The isotopically most enriched POM $\delta^{13} \mathrm{C}$ value of $-26.5 \%$ was determined for the sample from late 
Table 3. Stable carbon isotope $\left(\delta^{13} \mathrm{C}\right)$ and radiocarbon composition $\left({ }^{14} \mathrm{C}\right)$ of Lena Delta first terrace soil profiles and surface water particulate organic matter (2009-2011). Soil profile samples are given in meters below surface ( $\mathrm{mb.s.}$.). Not determined is denoted by n.d.

\begin{tabular}{|c|c|c|c|c|c|c|c|}
\hline Sample code & $\begin{array}{c}\delta^{13 \mathrm{C}} \\
(\% \circ \mathrm{VPDB})\end{array}$ & $\mathrm{fMC}^{\mathrm{a}}$ & $1 \sigma \mathrm{fMC}$ & $\begin{array}{c}\Delta^{14} \mathrm{C} \\
(\% \circ)\end{array}$ & $\begin{array}{c}\text { Conv. }{ }^{14} \mathrm{C} \text { age } \\
\text { (years BP) }\end{array}$ & $\begin{array}{l}1 \sigma^{14} \mathrm{C} \text { age } \\
\text { (years } \mathrm{BP} \text { ) }\end{array}$ & Lab ID \\
\hline \multicolumn{8}{|c|}{ Lena Delta first terrace } \\
\hline L09-12, 0.45 mb.s. & -26.8 & 0.8084 & 0.0039 & -197 & 1710 & 40 & OS-84097 \\
\hline L09-12, 1.35 mb.s. & -26.3 & 0.7311 & 0.0029 & -274 & 2510 & 30 & OS-84073 \\
\hline L09-12, 2.50 mb.s. & -25.2 & 0.7023 & 0.0025 & -303 & 2840 & 30 & OS-84072 \\
\hline L09-12, 4.70 mb.s. & -27.0 & 0.5708 & 0.0024 & -433 & 4500 & 35 & OS-84071 \\
\hline L09-12, 5.80 mb.s. & -25.1 & 0.6275 & 0.0027 & -377 & 3740 & 35 & OS-84070 \\
\hline L09-28, 0.30 mb.s. & -26.1 & 0.8015 & 0.0026 & -204 & 1780 & 25 & OS-84074 \\
\hline L09-28, 0.70 mb.s. & -26.6 & 0.5430 & 0.0028 & -461 & 4900 & 40 & OS-84087 \\
\hline \multicolumn{8}{|l|}{ Lena Delta Aug 2009} \\
\hline 1 & -30.5 & 0.7436 & 0.0029 & -262 & 2380 & 30 & OS-84096 \\
\hline 2 & -32.6 & 0.8173 & 0.0034 & -189 & 1620 & 35 & OS-84090 \\
\hline 3 & -30.9 & 0.8735 & 0.0031 & -133 & 1090 & 30 & OS-84093 \\
\hline 4 & -29.6 & 0.8259 & 0.0029 & -180 & 1540 & 25 & OS-84091 \\
\hline 5 & -31.3 & 0.8717 & 0.0031 & -134 & 1100 & 30 & OS-84098 \\
\hline 6 & -30.5 & 0.8524 & 0.0032 & -154 & 1280 & 30 & OS-84127 \\
\hline 10 & -29.8 & 0.8419 & 0.0032 & -164 & 1380 & 30 & OS-84101 \\
\hline 11 & -28.9 & 0.8458 & 0.0031 & -160 & 1340 & 30 & OS-84100 \\
\hline 12 & -30.6 & 0.8913 & 0.0031 & -115 & 925 & 25 & OS-84102 \\
\hline 13 & -29.9 & 0.8672 & 0.0036 & -139 & 1140 & 30 & OS-84133 \\
\hline 14 & -28.8 & 0.7971 & 0.0031 & -209 & 1820 & 30 & OS-84099 \\
\hline 19 & -34.2 & 0.9522 & 0.0042 & -55 & 395 & 35 & OS-84086 \\
\hline 21 & -27.1 & 0.8210 & 0.0028 & -185 & 1580 & 25 & OS-84088 \\
\hline Mean & -30.4 & 0.8462 & 0.0032 & -160 & 1353 & 30 & \\
\hline Standard deviation & 1.7 & 0.0480 & 0.0003 & 48 & 457 & 3 & \\
\hline \multicolumn{8}{|c|}{ Lena Delta TSM Jul/Aug 2010} \\
\hline 22 & -29.7 & 0.8344 & 0.0029 & -172 & 1450 & 30 & OS-95088 \\
\hline 24 & -29.4 & 0.8201 & 0.0034 & -186 & 1590 & 35 & OS-95100 \\
\hline 25 & -28.3 & 0.8288 & 0.0030 & -177 & 1510 & 30 & OS-95266 \\
\hline 26 & -28.9 & 0.8001 & 0.0028 & -206 & 1790 & 30 & OS-95382 \\
\hline 27 & -28.9 & 0.8386 & 0.0034 & -167 & 1410 & 30 & OS-95268 \\
\hline 28 & -28.8 & 0.8046 & 0.0035 & -201 & 1750 & 35 & OS-95380 \\
\hline 29 & -28.9 & 0.8353 & 0.0117 & -171 & 1440 & 110 & OS-94853 \\
\hline 30 & -30.2 & 0.8389 & 0.0033 & -167 & 1410 & 30 & OS-95238 \\
\hline 31 & -28.6 & 0.6139 & 0.0021 & -391 & 3920 & 25 & OS-95239 \\
\hline 32 & -29.6 & 0.8390 & 0.0033 & -167 & 1410 & 30 & OS-95267 \\
\hline 33 & -29.8 & 0.8125 & 0.0144 & -193 & 1670 & 140 & OS-94857 \\
\hline 35 & n.d. & 0.8299 & 0.0035 & -176 & 1500 & 35 & OS-95377 \\
\hline 36 & -30.4 & 0.8628 & 0.0150 & -143 & 1180 & 140 & OS-94858 \\
\hline Mean & -29.3 & 0.8122 & 0.0056 & -194 & 1695 & 54 & \\
\hline Standard deviation & 0.6 & 0.0594 & 0.0045 & 59 & 661 & 42 & \\
\hline \multicolumn{8}{|c|}{ Lena Delta TSM late May 2011} \\
\hline 37 & -26.5 & 0.6988 & 0.0028 & -306 & 2880 & 30 & OS-94760 \\
\hline \multicolumn{8}{|c|}{ Lena Delta TSM late Jun/early Jul 2011} \\
\hline 38 & -28.3 & 0.8623 & 0.0030 & -144 & 1190 & 30 & OS-95378 \\
\hline 42 & -29.3 & 0.8558 & 0.0033 & -151 & 1250 & 30 & OS-95384 \\
\hline 47 & -28.5 & 0.8519 & 0.0117 & -154 & 1290 & 110 & OS-94854 \\
\hline Mean & -28.7 & 0.8567 & 0.0060 & -150 & 1243 & 57 & \\
\hline Standard deviation & 0.4 & 0.0043 & 0.0040 & 4 & 41 & 38 & \\
\hline
\end{tabular}

${ }^{\mathrm{a}} \mathrm{fMC}$ : fraction modern carbon; ${ }^{\mathrm{b}}$ Conv. age: conventional radiocarbon age in years before present (years BP), i.e., before 1950. 
Table 4. End-member values used for the binary mixing models based on $\mathrm{POC}$ : $\mathrm{PN}$ and $\delta^{13} \mathrm{C}$, and for dual-carbon-isotope three-end-member mixing model. If not directly taken from the literature, individual values from the literature and this study used to calculate the end members can be found in Tables S1-S3.

\begin{tabular}{llllllll}
\hline & \multicolumn{2}{c}{ Scenario 1 POC : PN } & \multicolumn{2}{c}{ Scenario $2 \delta^{13} \mathrm{C}$} & \multicolumn{2}{c}{ Dual-carbon-isotope three-end-member mixing } \\
\hline & $\begin{array}{l}\text { riverine } \\
\text { phytoplankton }\end{array}$ & soil & $\begin{array}{l}\text { riverine } \\
\text { phytoplankton }\end{array}$ & soil & $\begin{array}{l}\text { riverine } \\
\text { phytoplankton }\end{array}$ & $\begin{array}{l}\text { Holocene } \\
\text { soils }\end{array}$ & $\begin{array}{l}\text { Ice Complex } \\
\text { deposits }\end{array}$ \\
\hline POC $:$ PN & $6 \pm 1^{1}$ & $23.7 \pm 11$ & - & - & - & - & - \\
$\delta^{13} \mathrm{C}(\% \circ$ vs. VPDB $)$ & - & - & $30.5 \pm 2.5$ & $-26.6 \pm 1.0$ & $30.5 \pm 2.5$ & $26.6 \pm 1.0$ & $-26.3 \pm 0.67^{3}$ \\
$\Delta^{14} \mathrm{C}(\%)$ & - & - & - & - & $41.9 \pm 4.2^{2}$ & $-282 \pm 133$ & $-940 \pm 84^{3}$ \\
\hline
\end{tabular}

${ }^{1}$ Meyers (1994) and references therein; ${ }^{2}$ average and standard deviation of atmospheric $\Delta^{14} \mathrm{C}$ values from May to August $2009-2011$ from Levin et al. (2013); ${ }^{3}$ from Vonk et al. (2012).

May 2011 (Table 3). The $\delta^{13} \mathrm{C}$ of Buor Khaya Bay surface water POM in August 2010 could only be determined for one of the samples, i.e., sample 36 , with $-30.4 \%$.

\subsubsection{Radiocarbon $\left({ }^{14} \mathrm{C}\right)$ concentration}

The $\Delta^{14} \mathrm{C}$ values of the two soil profiles decreased with depth from -197 to $-377 \%$ o for the riverbank profile L0912 and from -204 to $-466 \%$ for profile L09-28 (Table 3, Fig. 3a). The corresponding ${ }^{14} \mathrm{C}$ ages for both profiles together ranged from 1710 to 4900 years BP. Within profile L09-12 on Samoylov Island an age reversal was observed for the two oldest samples (Table 3), which is most likely due to allochthonous material that was transported to the delta from an upstream location. The same age reversal on Samoylov Island was also observed by Kuptsov and Lisitsin (1996). Overall, our $\Delta^{14} \mathrm{C}$ values reflect the late Holocene formation of these soils and fit within the range of ages determined for the Lena Delta first terrace (Bolshiyanov et al., 2015; Kuptsov and Lisitsin, 1996; Schwamborn et al., 2002).

As with other TSM parameters, the POM $\Delta{ }^{14} \mathrm{C}$ values showed strong spatial and interannual variability (Fig. $2 \mathrm{q}-\mathrm{t}$ and Fig. S1 in the Supplement). Lena Delta POM ${ }^{14} \mathrm{C}$ concentrations varied from -262 to $-55 \%$ o in August 2009 (mean of $-160 \%, n=13$ ), from -391 to $-143 \%$ in July/August 2010 (mean of $-194 \%, n=13$ ), and from -154 to $-144 \%$ in June/July 2011 (mean of $-150 \%$ o, $n=3$ ). The sample from late May 2011 showed a ${ }^{14} \mathrm{C}$ concentration of $-306 \%$, and the Buor Khaya Bay surface samples showed concentrations of $-176 \%$ (sample 35 ) and $-143 \%$ o (sample 36, Table 3, Fig. 2r-s). Overall these ${ }^{14} \mathrm{C}$ concentrations covered a range of ${ }^{14} \mathrm{C}$ ages from 395 to 3920 years BP. The samples with the lowest $\Delta^{14} \mathrm{C}$ values of -262 (sample 1) and $-391 \%$ (sample 31) were taken close to the Pleistocene IC deposits, which likely contributed to the local POM in the Lena River surface water.

\section{Discussion}

\subsection{Origin of organic matter in the Lena Delta}

Riverine particulate organic matter consists of a heterogeneous mixture derived from two major sources, i.e., terrestrial (e.g., fresh vegetation and litter; surface and deep soil horizons) and aquatic (phytoplankton/bacterial primary production). The terrestrial OM in the Lena River catchment can further be differentiated into two pools of different age: the late Pleistocene organic-rich IC deposits, particularly in the lowlands (0-400 m elevation; e.g., Grosse et al., 2013) and the Holocene permafrost soils. POC : PN ratios as well as $\delta^{13} \mathrm{C}$ and $\Delta^{14} \mathrm{C}$ values of bulk OM can be used to estimate terrestrial and aquatic contributions (e.g., Hedges and Oades, 1997). However, due to overlaps in soil/plant and al$\mathrm{gal} / \mathrm{bacterial}$ signatures, it might be difficult to unambiguously differentiate between terrestrial and aquatic sources.

Our POC: PN ratios from the summers 2009 and 2010 as well as spring 2011 vary largely throughout the delta (Tables 2 and S4) similar to the TSM and lignin phenol concentrations sampled during the same field trips (Winterfeld et al., 2015). The ratios range from 3.7 to 19.3 for all samples and seasons with mean atomic POC: PN ratios of 9.6 (2009), 7.6 (2010), and 7.8 (2011). Low POC: PN ratios, i.e., $\sim 6$, generally indicate high contributions from phytoplankton and/or bacterial primary production, while ratios $>20$ are indicative of soil and plant contributions (e.g., Hedges et al., 1997; Meyers and Lallier-Vergés, 1999). Based on these end members, our data from the summer and spring seasons would suggest a considerable fraction of primary production OM to be present in our samples.

However, due to possible sorption of inorganic nitrogen to clay minerals (Schubert and Calvert, 2001), our calculated POC : PN ratios might be too low, underestimating the soilderived OM fraction. This will be discussed in more detail in Sect. 4.3.1. Another possibility for lower but mainly soilderived POC: $\mathrm{PN}$ ratios could be the selective degradation of labile OM compared to total nitrogen (Kuhry and Vitt, 1996). 


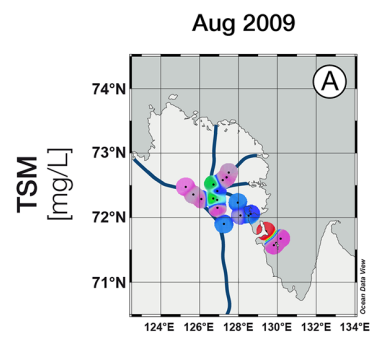

July/Aug 2010
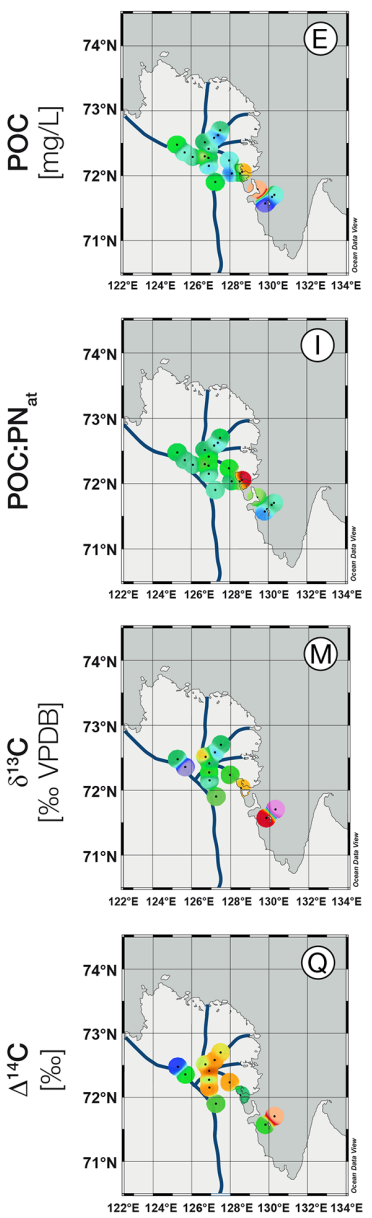
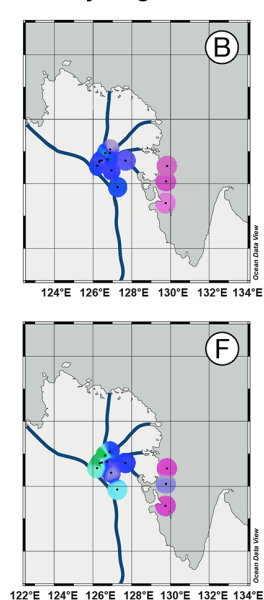

late May 2011
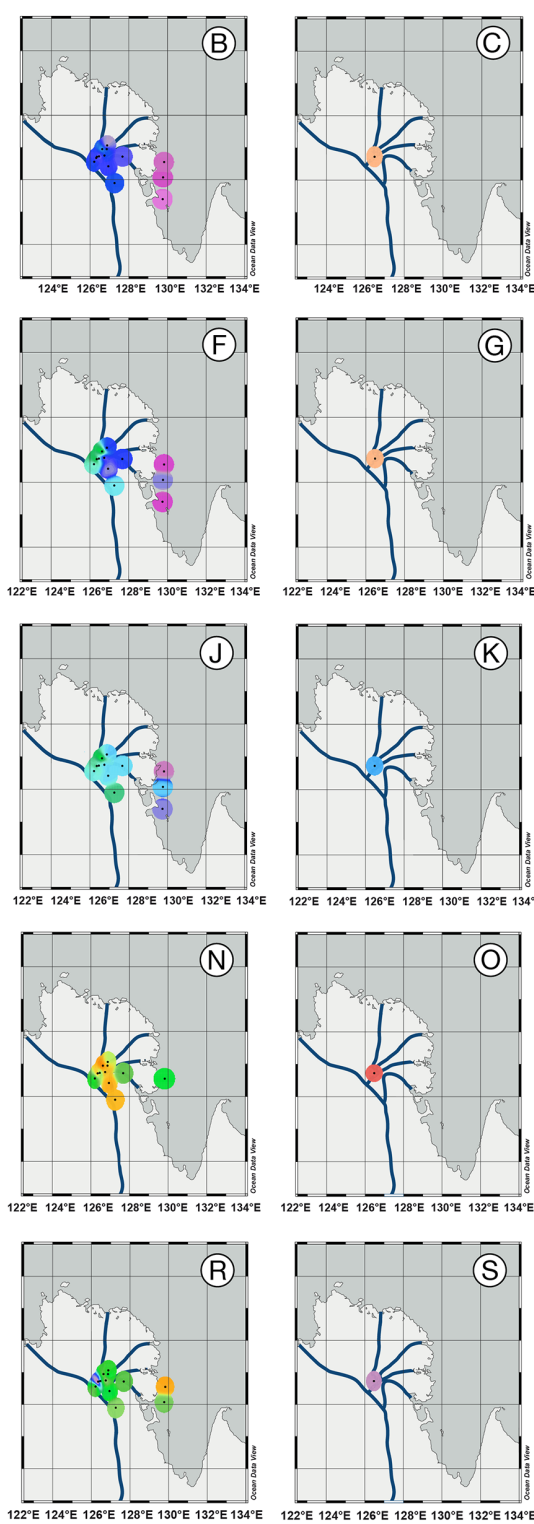

(B)

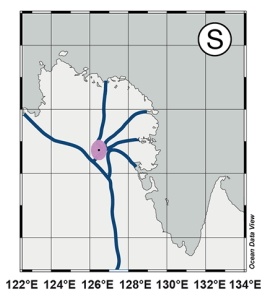

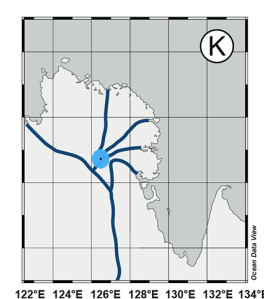

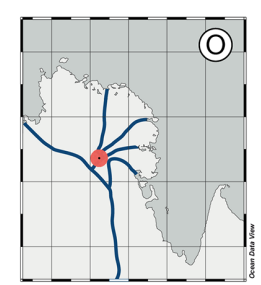

late June/early July 2011
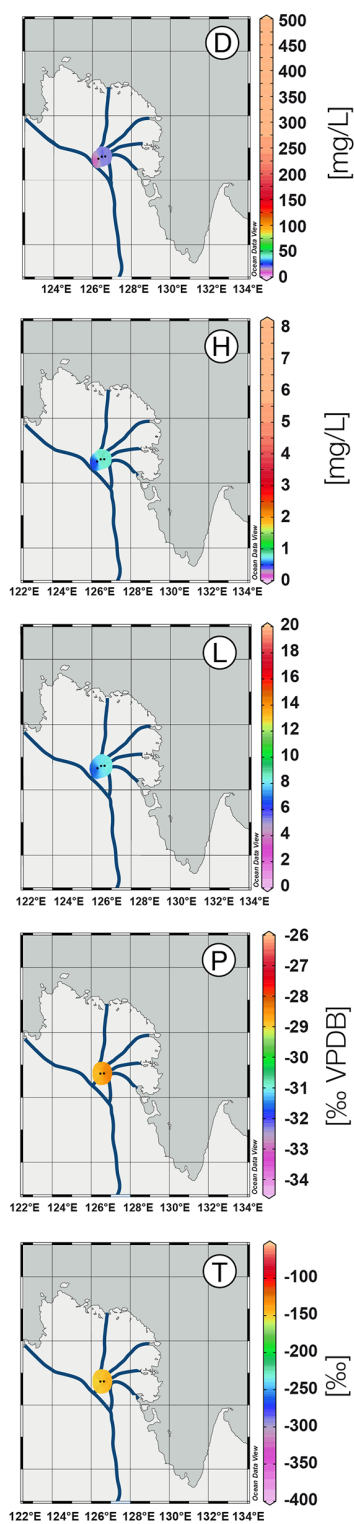

Figure 2. Spatial distribution of organic carbon concentrations, POC : PN ratios, and stable and radiocarbon isotopic composition in surface water total suspended matter (TSM) samples from 2009 to 2011. TSM concentrations of Aug 2009, July/Aug 2010, and late May 2011 (panels a-c) are from Winterfeld et al. (2015).

Analogous to the POC: $\mathrm{PN}$ ratios, the $\delta^{13} \mathrm{C}_{\mathrm{POM}}$ values point to a considerable contribution of primary production OM to our samples from 2009 to 2011 . The $\delta^{13} \mathrm{C}_{\mathrm{POM}}$ values of our samples taken in 2009-2011 vary over a broad range $(-34.2$ to $-26.5 \%$, Table 3$)$, which is similar to $\delta^{13} \mathrm{C}_{\mathrm{POM}}$ values previously published by Rachold and Hubberten (1999) for the Lena Delta and Lena River upstream the delta (-31.3 to $-25.7 \%$, July/August 1994/1995), by A-GRO (www.arcticgreatrivers.org) $\sim 900 \mathrm{~km}$ upstream the Lena Delta at Zhigansk ( -30.3 to $-25.2 \%$, MayAugust 2004-2010), and by Semiletov et al. (2011) for the
Lena Delta and Lena River ( -30.0 to $-25.0 \%$, AugustSeptember 1995-2008).

In general, the more enriched $\delta^{13} \mathrm{C}_{\mathrm{POM}}$ values (around $-27 \%$ ) reflect the dominant contribution from $\mathrm{C} 3$ plants and soils (e.g., Hedges et al., 1997) from the river catchment. The more depleted $\delta^{13} \mathrm{C}_{\mathrm{POM}}$ values $(\leq 29 \%$ o) point to mixing with riverine plankton utilizing dissolved inorganic carbon (DIC) with depleted $\delta^{13} \mathrm{C}$ signatures as suggested for the Lena River (Alling et al., 2012; Rachold and Hubberten, 1999). 

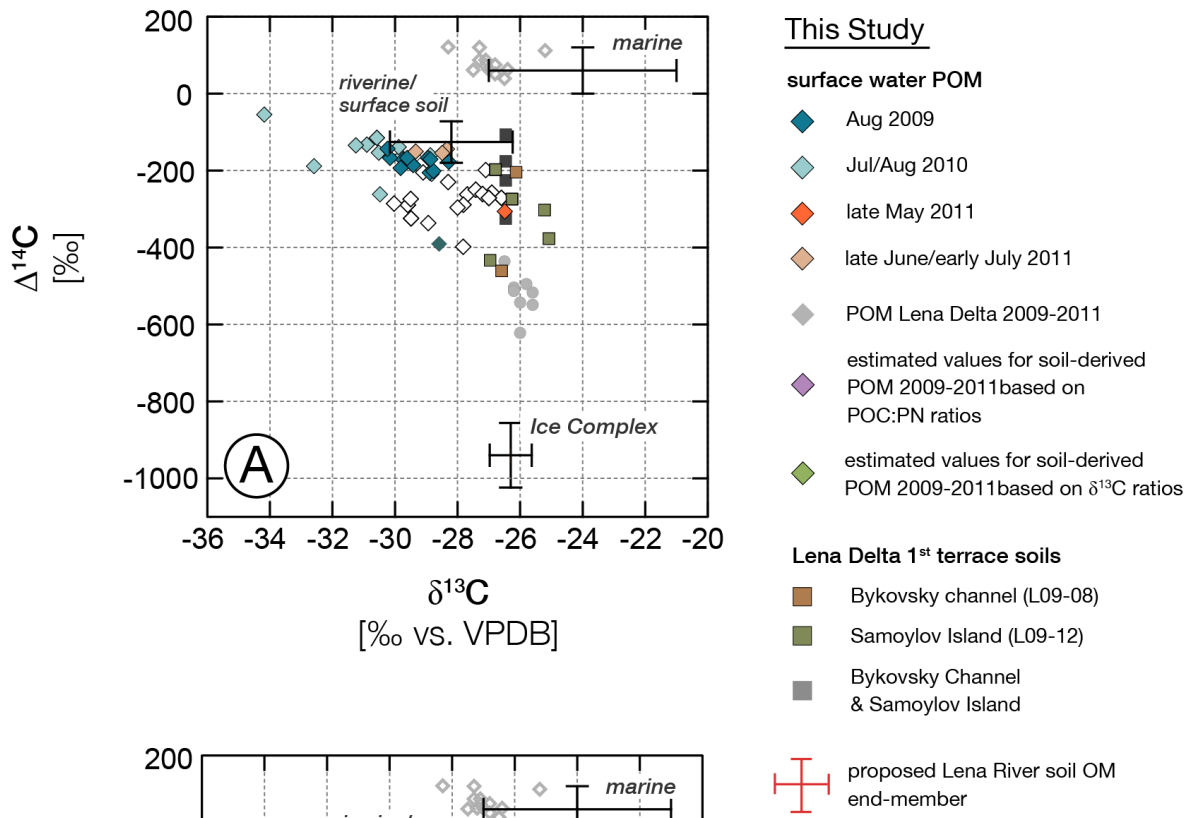

$\mapsto \dashv \begin{aligned} & \text { proposed Lena River soil OM } \\ & \text { end-member }\end{aligned}$

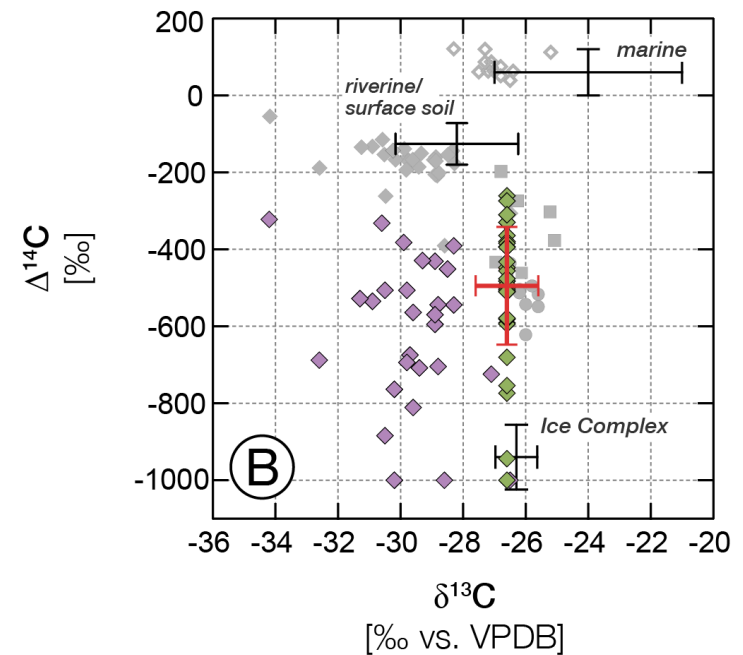

Literature Data

Samoylov polygon rim, upper $30 \mathrm{~cm}$

(Höfle et al., 2013)

DOM Lena River multiyear 2004-2010

$\checkmark \quad$ at Zhigansk gauging station (A-GRO)

$\checkmark \quad$ POM Lena River May-Sept. 2003-2011

at Zhigansk gauging station (A-GRO)

surface sediments Buor Khaya Bay Aug/Sept 2008 (Karlsson et al., 2011)

$\dashv$ by Vonk et al. (2012)

[\% vs. VPDB]

Figure 3. Stable and radiocarbon isotopic values of Lena Delta surface water POM of (a) this study and literature data as well as (b) estimated isotopic data of soil-derived POM based on POC : $\mathrm{PN}$ and $\delta{ }^{13} \mathrm{C}$ ratios. Ranges for different end members for topsoil, IC, and marine are taken from the literature.

The total flux of primary production OM in the Lena River is thought to be negligible due to low light penetration in the turbid waters (Cauwet and Sidorov, 1996; Sorokin and Sorokin, 1996). Yet, the surface water layer from which we took our TSM samples is characterized by an abundance of riverine plankton (Kraberg et al., 2013; Sorokin and Sorokin, 1996), which could explain the small soil-derived OM fraction.

In Sect. 4.3 we present the results of two binary and one three-end-member mixing models to estimate the soil OM contribution to our POM samples and to further calculate the ${ }^{14} \mathrm{C}$ concentration of the soil fraction.

\section{2 ${ }^{14} \mathrm{C}$ and age heterogeneity of POM $\left({ }^{14} \mathrm{CPOM}_{\mathrm{POM}}\right)$ in the Lena Delta}

Terrestrial POM enters a river predominantly by physical weathering of adjacent soils (Raymond and Bauer, 2001, and references therein). Compared to vegetation utilizing modern atmospheric ${ }^{14} \mathrm{CO}_{2}$, the bulk POM of soil is pre-aged. The specific residence time of POM in the soil before entering the river depends on various environmental factors like humidity, temperature, topography, soil type, size and topography of the catchment area (e.g., Kusch et al., 2010; Oades, 1988; Raymond and Bauer, 2001; Trumbore, 2009, 1993). Furthermore, the fluvial transport of POM (and TSM) is governed by hydrological characteristics like runoff, discharge and flow velocity, sedimentation along riverbanks and floodplains, and resuspension of deposited material. Therefore, the age of ter- 
restrial POM is a combination of its residence time within the soil plus its residence time within the river basin, which can differ substantially for different terrestrial POM fractions (lipids versus lignin) from Arctic watersheds (e.g., Feng et al., 2013; Gustafsson et al., 2011).

The Lena Delta and Buor Khaya Bay surface water ${ }^{14} \mathrm{C}_{\mathrm{POM}}$ concentrations presented here are depleted with respect to the current atmospheric ${ }^{14} \mathrm{CO}_{2}$ (Table 3). The $\Delta^{14} \mathrm{C}$ values range from -391 to $-55 \%$ o for 2009 to 2011 , translating into ${ }^{14} \mathrm{C}$ ages $>400$ years and up to 3920 years BP for samples taken close to the Pleistocene IC deposits of Kurungnakh Island (Fig. 2q-t, Table 3). These results are within the range of reported $\Delta^{14} \mathrm{C}$ values for surface water POM offshore of the Lena Delta and influenced by Lena River outflow (Karlsson et al., 2011). Based on these results it seems reasonable to assume that a large fraction of Lena Delta POM originates from physical weathering of relatively young Holocene soils (active layer) of the first delta terrace and south of the delta.

However, soils outcropping along the Lena River south of the delta can be substantially older than late Holocene ages (Kuptsov and Lisitsin, 1996), including some areas of Pleistocene IC deposits (Grosse et al., 2013). Also, OM within the active layer and shallow permafrost table can be as old as 3000 years BP in the Lena Delta $(30 \mathrm{~cm}$ below surface, Höfle et al., 2013) or more than $>10000$ years BP south of the delta (Kuptsov and Lisitsin, 1996). As shown by the lignin phenol composition of Lena Delta POM (Winterfeld et al., 2015), approximately half of the surface water POM is derived from the catchment south of the delta with considerable contributions from delta soils, particularly in the summer season, when riverbank erosion is strongest. Considering that, we would expect generally older POM ${ }^{14} \mathrm{C}$ ages. Additionally, riverbank erosion contributes $\mathrm{POM}$ covering the ${ }^{14} \mathrm{C}$ age range of the whole soil profile, not only from the active layer.

One possible explanation for our relatively young POM ${ }^{14} \mathrm{C}$ ages could be the contribution of plankton-derived $\mathrm{OM}$ with a rather modern ${ }^{14} \mathrm{C}$ concentration concealing the "true" age of soil-derived OM. Phytoplankton-derived OM contribution was also suggested to be the reason for relatively young POM from the Ob' River inferred from a core of a floodplain lake (Dickens et al., 2011). Although the overall contribution and flux of autochthonous phytoplankton OM in the Lena River is rather small or even negligible due to the high turbidity and low light penetration (Cauwet and Sidorov, 1996; Sorokin and Sorokin, 1996), phytoplankton can be quite abundant in the surface water (Kraberg et al., 2013; Sorokin and Sorokin, 1996), which we sampled for our POM analyses. In the following Sect. 4.3 we present results from two different approaches to quantify the soil OM fraction in our samples and further estimate its ${ }^{14} \mathrm{C}$ concentration based on the assumption of plankton-derived OM with modern $\Delta^{14} \mathrm{C}$ values.

\subsection{Quantitative POM source determination and soil ${ }^{14} \mathrm{C}$ concentrations}

\subsubsection{Binary mixing model scenario 1}

POC : PN ratios around 6 are usually associated with OM derived from algal/bacterial primary production and higher ratios of $>20$ with OM derived from soils (Hedges et al., 1997; Meyers and Lallier-vergés, 1999 and references therein). However, as noted above (Sect. 4.1) adsorption of inorganic nitrogen derived from OM decomposition (e.g., ammonium) to clay minerals (Schubert and Calvert, 2001), which is not accounted for when determining the total PN content, may additionally affect the POC: $\mathrm{PN}$ ratio in TSM, leading to lower values than would be expected from mixing of the two end members alone. Likewise, selective degradation of labile organic carbon (Kuhry and Vitt, 1996) would also result in lower POC: PN ratios. Both processes would lead to low estimates of the soil-derived OM contribution and suggest a higher contribution from plankton. Both explanations were also suggested by Sanchéz-García et al. (2011) for POM in the Laptev Sea offshore of the Lena Delta with unusually low POC : $\mathrm{PN}$ ratios.

In order to estimate the inorganic nitrogen content for our sample sets from each year, we used the intercept of the POC versus $\mathrm{PN}$ content regression line at $\mathrm{POC}=0$ (Fig. S2). By subtracting these amounts from the analyzed total PN content of the respective samples, we could calculate new soil POC: $\mathrm{PN}$ ratios (POC: $\mathrm{PN}_{\mathrm{NEW}}$ ) for our samples (Table S4 Supplement). Based on these POC: $\mathrm{PN}_{\mathrm{NEW}}$ ratios (and their uncertainty, derived from the standard error of the POC versus PN regressions), we calculated the soil-derived fraction within our POM samples using a simple two-end-member mixing model as follows:

$$
\begin{aligned}
& \mathrm{POC}: \mathrm{PN}_{\mathrm{NEW}}=f_{\text {soil }} \times \mathrm{POC}: \mathrm{PN}_{\text {soil }}+f_{\text {plankton }} \\
& \times \mathrm{POC}: \mathrm{PN}_{\text {plankton }} \\
& \text { and } 1=f_{\text {soil }}+f_{\text {plankton }},
\end{aligned}
$$

where POC: $\mathrm{PN}_{\mathrm{NEW}}$ is the corrected value of the POM sample (Table S4). As the end member for POC : $\mathrm{PN}_{\text {soil }}$ we chose $23.7 \pm 11$ (Tables 4 and S1), which is an average calculated from Lena Delta first terrace soils presented in Winterfeld et al. (2015) and delta soils as well as soil from the Lena River watershed covering the taiga to tundra transition from Höfle et al. (2013), Zubrzycki (2013), and Zubrzycki e al. (2012, individual values in Table S1). The POC: $\mathrm{PN}_{\text {plankton }}$ endmember value is $6 \pm 1$ (Table 4; e.g., Meyers, 1994).

The calculated soil-derived OM fractions of Lena Delta POM varied from 0.26 to 0.70 (mean of $0.35, n=21$, Table 5) for summer 2009, from 0.26 to 0.44 (mean of 0.34 , $n=11$ ) for summer 2010, and from 0.39 to 0.50 (mean of $0.43, n=9$ ) for late June/early July 2011 (Table 5). We used the POC versus PN (wt \%) regression line from the summer 2010 samples within the delta to correct the two samples taken outside of the delta in the Buor Khaya Bay. They 
Table 5. Soil fractions calculated based on POC : $\mathrm{PN}$ ratios and $\delta^{13} \mathrm{C}$ values and associated estimated ${ }^{14} \mathrm{C}$ concentrations of the soil-derived POM fraction. Soil fractions are given with standard deviation $(1 \sigma) . \Delta^{14} \mathrm{C}$ values are given with lower quantile (q16) and upper quantile (q84), representing the $68 \%$ confidence interval ( $1 \sigma$ for normal distributions). $\Delta^{14} \mathrm{C}$ values lower than $-1000 \%$ were marked as "fossil". Not determined denoted by n.d.

\begin{tabular}{|c|c|c|c|c|c|c|c|c|c|c|}
\hline \multirow[b]{2}{*}{$\begin{array}{l}\text { Sample } \\
\text { code }\end{array}$} & \multicolumn{5}{|c|}{ POC : PN based estimates } & \multicolumn{5}{|c|}{ Plankton $\delta^{13} \mathrm{C}$-based estimates } \\
\hline & $\begin{array}{l}\text { Fraction soil } \\
\text { POM }\end{array}$ & $\begin{array}{l}\Delta^{14} \mathrm{C}_{\mathrm{POC}: \mathrm{PN}} \\
(\% \circ)\end{array}$ & $\begin{array}{l}\Delta^{14} \mathrm{C}_{\text {POC }: P N} \\
\mathrm{q} 16(\%)\end{array}$ & $\begin{array}{l}\Delta^{14} \mathrm{C}_{\mathrm{POC}}: \mathrm{PN} \\
\mathrm{q} 84(\% \circ)\end{array}$ & $\begin{array}{l}\text { Conv. }{ }^{14} \mathrm{C}_{\mathrm{POC}} \text { : } \mathrm{PN} \\
\text { age (years BP) }\end{array}$ & $\begin{array}{l}\text { Fraction soil } \\
\text { POM }_{\delta}{ }^{13} C\end{array}$ & $\begin{array}{l}\Delta^{14} \mathrm{C}_{\delta^{13} C} \\
(\% \circ)\end{array}$ & $\begin{array}{l}\Delta^{14} \mathrm{C}_{\delta^{13} C} \\
\mathrm{q} 16(\% \circ)\end{array}$ & $\begin{array}{l}\Delta^{14} \mathrm{C}_{\delta}{ }^{13} C \\
\mathrm{q} 84(\% \circ)\end{array}$ & $\begin{array}{l}\text { Conv. }{ }^{14} \mathrm{C}_{\delta 13 C} \\
\text { age (years BP) }\end{array}$ \\
\hline \multicolumn{11}{|c|}{ Lena Delta TSM Aug 2009} \\
\hline 1 & $0.33 \pm 0.18$ & -884 & fossil & -550 & 17250 & $0.31 \pm 017$ & -944 & fossil & -585 & 23100 \\
\hline 2 & $0.32 \pm 0.18$ & -688 & fossil & -416 & 9300 & $0.17 \pm 0.12$ & fossil & - & - & fossil \\
\hline 3 & $0.30 \pm 0.18$ & -535 & fossil & -313 & 6100 & $0.28 \pm 0.16$ & -591 & fossil & -354 & 7120 \\
\hline 4 & $0.26 \pm 0.17$ & -811 & fossil & -465 & 13320 & $0.40 \pm 0.20$ & -511 & -967 & -327 & 5690 \\
\hline 5 & $0.31 \pm 0.18$ & -528 & fossil & -314 & 5970 & $0.24 \pm 0.15$ & -681 & fossil & -399 & 9120 \\
\hline 6 & $0.36 \pm 0.19$ & -506 & -998 & -492 & 5600 & $0.31 \pm 0.17$ & -594 & fossil & -363 & 7180 \\
\hline 7 & $0.27 \pm 0.18$ & n.d. & n.d. & n.d. & n.d. & n.d. & n.d. & n.d. & n.d. & n.d. \\
\hline 8 & $0.29 \pm 0.18$ & n.d. & n.d. & n.d. & n.d. & n.d. & n.d. & n.d. & n.d. & n.d. \\
\hline 9 & $0.38 \pm 0.19$ & n.d. & n.d. & n.d. & n.d. & n.d. & n.d. & n.d. & n.d. & n.d. \\
\hline 10 & $0.38 \pm 0.19$ & -506 & -985 & -322 & 5600 & $0.38 \pm 0.19$ & -500 & -953 & -317 & 5510 \\
\hline 11 & $0.32 \pm 0.18$ & -595 & fossil & -359 & 7200 & $0.50 \pm 0.21$ & -364 & -655 & -245 & 3580 \\
\hline 12 & $0.42 \pm 0.20$ & -332 & -625 & -213 & 3190 & $0.30 \pm 0.17$ & -483 & -981 & -291 & 5240 \\
\hline 13 & $0.43 \pm 0.20$ & -382 & -709 & -249 & 3810 & $0.37 \pm 0.19$ & -451 & -899 & -282 & 4760 \\
\hline 14 & $0.34 \pm 0.19$ & -704 & fossil & -434 & 9720 & $0.51 \pm 0.22$ & -447 & -793 & -307 & 4700 \\
\hline 15 & $0.38 \pm 0.20$ & n.d. & n.d. & n.d. & n.d. & n.d. & n.d. & n.d. & n.d. & n.d. \\
\hline 16 & $0.70 \pm 0.16$ & n.d. & n.d. & n.d. & n.d. & n.d. & n.d. & n.d. & n.d. & n.d. \\
\hline 17 & $0.36 \pm 0.18$ & n.d. & n.d. & n.d. & n.d. & n.d. & n.d. & n.d. & n.d. & n.d. \\
\hline 18 & $0.38 \pm 0.19$ & n.d. & n.d. & n.d. & n.d. & n.d. & n.d. & n.d. & n.d. & n.d. \\
\hline 19 & $0.27 \pm 0.17$ & -322 & -718 & -174 & 3060 & $0.12 \pm 0.09$ & -774 & fossil & -407 & 11890 \\
\hline 20 & $0.38 \pm 0.20$ & n.d. & n.d. & n.d. & n.d. & n.d. & n.d. & n.d. & n.d. & n.d. \\
\hline 21 & $0.30 \pm 0.20$ & -724 & fossil & -413 & 10280 & $0.75 \pm 0.20$ & -261 & -377 & -214 & 2370 \\
\hline \multicolumn{11}{|c|}{ Lena Delta TSM Jul/Aug 2010} \\
\hline 22 & $0.30 \pm 0.18$ & -675 & fossil & -402 & 8970 & $0.39 \pm 0.20$ & -505 & -976 & -322 & 5590 \\
\hline 24 & $0.30 \pm 0.18$ & -708 & fossil & -424 & 9810 & $0.43 \pm 0.20$ & -491 & -914 & -320 & 5370 \\
\hline 25 & $0.37 \pm 0.19$ & -544 & fossil & -349 & 5100 & $0.59 \pm 0.22$ & -330 & -553 & -237 & 3160 \\
\hline 26 & n.d. & n.d. & n.d. & n.d. & n.d. & $0.50 \pm 0.21$ & -456 & -807 & -308 & 4830 \\
\hline 27 & $0.44 \pm 0.20$ & -431 & -787 & -284 & 3760 & $0.50 \pm 0.21$ & -456 & -679 & -256 & 3780 \\
\hline 28 & $0.41 \pm 0.20$ & -544 & fossil & -355 & 5360 & $0.51 \pm 0.21$ & -380 & -756 & -296 & 4490 \\
\hline 29 & $0.35 \pm 0.18$ & -570 & fossil & -353 & 5890 & $0.50 \pm 0.21$ & -384 & -690 & -258 & 3830 \\
\hline 30 & $0.26 \pm 0.17$ & -764 & fossil & -437 & 11700 & $0.34 \pm 0.18$ & -581 & fossil & -360 & 6930 \\
\hline 31 & $0.31 \pm 0.18$ & fossil & - & - & fossil & $0.54 \pm 0.22$ & -754 & fossil & -536 & 11210 \\
\hline 32 & $0.34 \pm 0.19$ & -564 & fossil & -349 & 6190 & $0.40 \pm 0.20$ & -476 & -903 & -306 & 5130 \\
\hline 33 & $0.32 \pm 0.18$ & -694 & fossil & -419 & 8890 & $0.38 \pm 0.19$ & -579 & fossil & -366 & 6890 \\
\hline 34 & $0.36 \pm 0.21$ & n.d. & n.d. & n.d. & n.d. & n.d. & n.d. & n.d. & n.d. & n.d. \\
\hline 35 & $0.39 \pm 0.20$ & 515 & -997 & -329 & 5190 & n.d. & n.d. & n.d. & n.d. & n.d. \\
\hline 36 & $0.12 \pm 0.13$ & fossil & & n.d. & $0.34 \pm 0.18$ & -510 & fossil & -312 & 5670 & \\
\hline \multicolumn{11}{|c|}{ Lena Delta TSM late May 2011} \\
\hline 37 & $0.13 \pm 0.13$ & fossil & & n.d. & $0.80 \pm 0.19$ & -393 & -539 & -341 & 3950 & \\
\hline \multicolumn{11}{|c|}{ Lena Delta TSM late Jun/early Jul 2011} \\
\hline 38 & $0.43 \pm 0.19$ & -391 & -704 & -258 & 2870 & $0.59 \pm 0.22$ & -274 & -460 & -196 & 2510 \\
\hline 39 & $0.50 \pm 0.20$ & n.d. & n.d. & n.d. & n.d. & n.d. & n.d. & n.d. & n.d. & n.d. \\
\hline 41 & $0.39 \pm 0.19$ & n.d. & n.d. & n.d. & n.d. & n.d. & n.d. & n.d. & n.d. & n.d. \\
\hline 42 & $0.41 \pm 0.19$ & -429 & -798 & -280 & 3340 & $0.44 \pm 0.21$ & -394 & -738 & -256 & 3970 \\
\hline 43 & $0.43 \pm 0.19$ & n.d. & n.d. & n.d. & n.d. & n.d. & n.d. & n.d. & n.d. & n.d. \\
\hline 44 & $0.41 \pm 0.19$ & n.d. & n.d. & n.d. & n.d. & n.d. & n.d. & n.d. & n.d. & n.d. \\
\hline 45 & $0.43 \pm 0.19$ & n.d. & n.d. & n.d. & n.d. & n.d. & n.d. & n.d. & n.d. & n.d. \\
\hline 46 & $0.44 \pm 0.19$ & n.d. & n.d. & n.d. & n.d. & n.d. & n.d. & n.d. & n.d. & n.d. \\
\hline 47 & $0.40 \pm 0.19$ & -451 & -848 & -290 & 3620 & $0.56 \pm 0.22$ & -310 & -534 & -215 & 2920 \\
\hline
\end{tabular}

had calculated soil fractions of 0.39 (sample 35) and 0.12 (sample 36). The same was done for the single sample from late May 2011. We used the regression line from the samples taken 4 weeks later in June/July, and the soil fraction of sample 37 was 0.13 (Table 5). Note that these soil- and plankton-derived OM fractions can only serve as rough estimates. Without determining the particulate organic nitrogen directly for every sample, our POC : $\mathrm{PN}_{\mathrm{NEW}}$ ratios (Table $\mathrm{S} 4$ ) might be highly over- and underestimating OM fractions in individual samples.

The calculated soil and plankton OM fractions $\left(f_{\text {soil }}\right.$ and $f_{\text {plankton, }}$ Table 5) were further used in an isotopic mass balance to determine the ${ }^{14} \mathrm{C}$ concentration of the soil fraction assuming the plankton-derived $\mathrm{OM}$ is modern 
$\left(\Delta^{14} \mathrm{C}_{\text {plankton }}=41.9 \pm 4.2 \%\right.$, Table 4$):$

$f_{\text {POM }} \times \Delta^{14} C_{\text {POM }}=f_{\text {soil }} \times \Delta^{14} C_{\text {soil }}$

$+f_{\text {plankton }} \times \Delta^{14} C_{\text {plankton }}$

and $f_{\mathrm{POM}}=f_{\text {soil }}+f_{\text {plankton }}$,

where $f_{\mathrm{POM}}, f_{\text {soil }}$, and $f_{\text {plankton }}$ are the fractions of POM and soil- and plankton-derived OM, and $\Delta{ }^{14} \mathrm{C}_{\mathrm{POM}}, \Delta^{14} \mathrm{C}_{\text {soil }}$, and $\Delta^{14} \mathrm{C}_{\text {plankton }}$ are the $\Delta^{14} \mathrm{C}$ values of these sources. As noted above, $41.9 \pm 4.2 \%$ is assumed as a maximum estimate for $\Delta^{14} \mathrm{C}_{\text {plankton }}$ based on atmospheric $\mathrm{CO}_{2} \Delta{ }^{14} \mathrm{C}$ values for May to August 2009-2011 from the Schauinsland observatory, Germany.

The results of the newly calculated soil $\Delta^{14} \mathrm{C}$ values using POC : $\mathrm{PN}_{\mathrm{NEW}}$ ratios $\left(\Delta^{14} \mathrm{C}_{\mathrm{POC}}\right.$ : $\left.\mathrm{PN}\right)$ to partition between soil- and plankton-derived OM are shown in Table 5. The soil $\Delta{ }^{14} C_{\text {POC }}$ : PN values range from -884 to $-322 \%$ for the sampling period of 2009-2011, translating into soil ${ }^{14} \mathrm{C}$ ages $>3000$ years BP with an average of 6700 years BP (Table 5). Analogous to the two comparatively old bulk ${ }^{14} \mathrm{C}_{\mathrm{POM}}$ ages off Kurungnakh Island taken in 2009 and 2010 (Table 3), the calculated ${ }^{14} \mathrm{C}_{\mathrm{POC}}$ : PN age for sample 1 was 17250 years $\mathrm{BP}$ and yielded a fossil age (>50000 years BP) for sample 31. Considering that the riverbank outcrops of Kurungnakh Island cover an age range of approximately $100 \mathrm{kyr}$ with organic-rich IC deposits of about $50 \mathrm{kyr}$ (Wetterich et al., 2008), these ${ }^{14} \mathrm{C}$ ages seem to be realistic.

Again, the uncertainties associated with the contribution of inorganic nitrogen to our total PN contents are rather high, resulting in a relatively rough estimation of soil and plankton $\mathrm{OM}$ fractions. These uncertainties are further affecting the calculation of the soil $\Delta^{14} \mathrm{C}_{\mathrm{POC}}$ : $\mathrm{PN}$ concentrations. That means the calculated ${ }^{14} \mathrm{C}$ ages are estimates. Yet, they demonstrate that a possible underestimation of soil-derived $\mathrm{OM}$ ages can be considerable.

\subsubsection{Binary mixing model scenario 2}

Similar to the approach discussed in Sect. 4.3.1, we used a second scenario based on $\delta^{13} \mathrm{C}$ values to distinguish between soil- and plankton-derived OM in our Lena Delta POM samples. The vegetation in the Lena River catchment (taiga and tundra) is dominated by $\mathrm{C} 3$ plants with a $\delta^{13} \mathrm{C}$ of around -25 to $-27 \%$ (Rachold and Hubberten, 1999). This is also reflected in our $\delta^{13} \mathrm{C}$ data from the first delta terrace soils, with an average of $-26.2 \%$ o $(n=7$, Table 3). Bird et al. (2002) determined the $\delta^{13} \mathrm{C}$ composition of taiga and tundra soils (excluding peatlands) along Yenisey River on a latitudinal transect. For the binary mixing model we used a soil OM end-member value of $-26.6 \pm 1 \%$ o (Table 4 ), which is a combination of $\delta^{13} \mathrm{C}$ data from this study and the literature (Table S2; Bird et al., 2002; Pitkänen et al., 2002; Xu et al., 2009) covering tundra and taiga soils in Siberia and Alaska.

The $\delta^{13} \mathrm{C}$ composition of riverine plankton POM depends on the fractionation between phytoplankton and dissolved in- organic carbon (DIC). The distribution of the different DIC fractions (dissolved $\mathrm{CO}_{2}$, bicarbonate $\left(\mathrm{HCO}_{3}^{-}\right)$, and carbonate ion $\left(\mathrm{CO}_{3}^{2-}\right)$ varies depending on temperature and $\mathrm{pH}$. In the lower reaches of the Lena River and the Lena Delta, $>90 \%$ of the DIC is made up of bicarbonate (Alling et al., 2012), i.e., the $\delta^{13} \mathrm{C}$ of bicarbonate represents the $\delta^{13} \mathrm{C}$ of DIC. Sources for DIC are generally the $\mathrm{CO}_{2}$ derived from soil $\mathrm{OM}$ degradation, $\mathrm{CO}_{2}$ released during the dissolution of carbonates, and $\mathrm{CO}_{2}$ from the atmosphere. The Lena River geochemistry is mainly influenced by carbonate weathering and groundwater in the summer season (Gordeev and Sidorov, 1993). Assuming a fractionation of $-22.5 \pm 2.5 \%$ o between phytoplankton and DIC (Mook and Tan, 1991) and a $\delta^{13} C_{\text {DIC }}$ of $-8 \%$ for the Lena Delta (Alling et al., 2012), a plankton $\delta^{13} \mathrm{C}$ end-member value of $-30.5 \pm 2.5 \%$ o would be expected. Similar or more depleted $\delta^{13} \mathrm{C}$ values of bicarbonate and phytoplankton POM were also determined in the Yenisey and $\mathrm{Ob}$ ' rivers (Galimov et al., 2006) and in temperate estuaries (e.g., Ahad et al., 2008; Chanton and Lewis, 2002). Our most depleted $\delta^{13} \mathrm{C}_{\mathrm{POM}}$ of $-34.2 \%$ for a sample from the summer 2009 (Table 3) is even lower than the plankton end member used here $\left(\delta^{13} \mathrm{C}_{\text {plankton }}=-30.5 \%\right.$ o $)$. The sample location is offshore of Muostakh Island (Fig. 1b) and influenced by mixing with marine waters, which complicates the DIC composition and processes affecting $\delta^{13} \mathrm{C}$ of DIC (Alling et al., 2012).

We used the following two-end-member model to estimate the soil- and plankton-derived OM fractions $\left(f_{\text {soil }}, f_{\text {plankton }}\right)$ of our POM samples:

$\delta^{13} C_{\text {POM }}=f_{\text {soil }} \times \delta^{13} C_{\text {soil }}+f_{\text {plankton }} \times \delta^{13} C_{\text {plankton }}$

and $1=f_{\text {soil }}+f_{\text {plankton }}$,

where $\delta^{13} \mathrm{C}_{\mathrm{POM}}$ is the analyzed $\delta^{13} \mathrm{C}$ value of our POM samples (Table 3), $\delta^{13} \mathrm{C}_{\text {soil }}$ is the soil end-member value of $-26.6 \pm 1 \%$, and $\delta^{13} \mathrm{C}_{\text {plankton }}$ is plankton end-member value of $-30.5 \pm 2.5 \%$ o (Tables 4 and S3).

The calculated soil OM fractions varied from 0.12 to 0.51 in summer 2009 (mean of $0.32, n=12$, Table 5), from 0.34 to 0.59 in summer 2010 (mean of $0.45, n=12$ ), and from 0.44 to 0.59 in spring 2011 (mean of $0.53, n=3$ ). The Buor Khaya Bay POM sample 21 showed a soil fraction of 0.75 and the spring freshet value (sample 37) a soil fraction of 0.80 (Table 5). As discussed above in Sect. 4.3.1, these soil $\mathrm{OM}$ fractions are rough estimates in the absence of direct plankton determination.

Furthermore, $\Delta^{14} \mathrm{C}$ values of the soil-derived $\mathrm{OM}$ fraction were calculated for the contribution of modern plankton $\mathrm{OM}$ as described in Sect. 4.3.1 using Eqs. (3) and (4). Because the soil contributions calculated in this scenario are slightly higher than in the POC: PN-based scenario, the $\Delta^{14} \mathrm{C}$ calculations resulted in estimates that are less radiocarbon-depleted compared to the POC: $\mathrm{PN}$ scenario (Table 5). Nonetheless, the $\Delta^{14} \mathrm{C}$ values based on the $\delta^{13} \mathrm{C}$ end-member model are considerably ${ }^{14} \mathrm{C}$-depleted compared 
to bulk POM ${ }^{14} \mathrm{C}$ concentrations. The estimated $\Delta^{14} \mathrm{C}$ values range from -944 to $-495 \%$ for all samples for 2009 2011 representing ${ }^{14} \mathrm{C}$ ages from 23100 to 2370 years BP (Table 5). The oldest samples are, again, the ones taken close to Pleistocene IC deposits (samples 1 and 31).

\subsubsection{Comparison of scenario 1 and 2}

Of all samples from 2009 to 2011 presented here, 28 samples have a soil fraction estimate from both scenarios. For these samples the POC: PN scenario gives a lower mean soil fraction of 0.33 compared to 0.43 from scenario 2 (based on $\delta^{13} \mathrm{C}$, Fig. S3). The comparison demonstrates that the error estimates determined in the end-member calculation are realistic, as only 6 (2) of 28 samples are outside 1 (2) standard deviations of the estimated error. As the uncertainty of the estimates is high, both estimates are only weakly correlated (removing the clear outlier sample 37, we get $R=0.3$, $p=0.1)$.

Because we assumed a modern ${ }^{14} \mathrm{C}$ value for the phytoplankton $\mathrm{OM}$, the estimated soil ${ }^{14} \mathrm{C}$ concentrations are related to the amount of soil OM calculated in both scenarios. The lower mean fraction in scenario 1 therefore resulted in a lower mean soil $\Delta{ }^{14} \mathrm{C}$ value of $-569 \%$ o $\left({ }^{14} \mathrm{C}\right.$ age $=6700$ year BP, $n=26)$ compared to $-495 \%$ o $\left({ }^{14} \mathrm{C}\right.$ age $=5430$ years BP, $n=28$ ) for scenario 2 . Besides the spring freshet sample from 2011, the two samples with the lowest bulk $\Delta^{14} \mathrm{C}$ values (sample 1 and 31, Table 3) also showed one of the lowest estimated soil $\Delta{ }^{14} \mathrm{C}$ values, namely $-884 \%$ and radiocarbon-free (fossil) for scenario 1 as well as -944 and $-754 \%$ for scenario 2 . The two samples were taken close to IC deposits within the delta, which illustrates the locally pronounced influence of these deposits. Another sample standing out is sample 19, taken outside the delta close to Muostakh Island, which is also composed of IC deposits (Fig. 1b). Its bulk POM $\Delta^{14} \mathrm{C}$ value was highest $\left(\Delta^{14} \mathrm{C}=-55 \%\right.$, Table 3$)$, pointing to comparatively young $\mathrm{OM}$, and its $\delta^{13} \mathrm{C}$ value was lowest $(-34.2 \%$ ), pointing to a rather high contribution of phytoplankton. This is in our line of argumentation assuming a contribution of planktonderived OM with a modern $\Delta^{14} \mathrm{C}$ value. Because of our chosen end members, the soil fraction in sample 19 was rather small in the ${ }^{13} \mathrm{C}$-based scenario, and the resulting $\Delta^{14} \mathrm{C}$ value of the soil fraction was $\left({ }^{14} \mathrm{C}\right.$ age of 11890 years BP) the second lowest at $-774 \%$.

In contrast to scenario 1 , it is more obvious in scenario 2 that the POM samples taken in late June/early July 2011 are more enriched in ${ }^{14} \mathrm{C}$ (younger) than the POM samples taken later in the summer (August 2009 and July/August 2010). Similar observation were made for DOM $\Delta{ }^{14} \mathrm{C}$ concentrations of the Lena River at Zhigansk $\sim 900 \mathrm{~km}$ south of the delta (Raymond et al., 2007) and the Kolyma River in East Siberia (Neff et al., 2006). Their explanation was that, due to the deepening of the active layer in summer, older soil layers are accessible for meltwater and groundwater, contribut- ing an older DOM signature to the river than in spring, when most soil is still frozen. A comparable scenario could explain estimated $\Delta^{14} \mathrm{C}$ concentration decreasing from spring freshet to summer. In addition to active layer deepening, riverbank erosion is strongest during the summer and might contribute a considerable amount of soil-derived OM with a large ${ }^{14} \mathrm{C}$ age range to the Lena Delta surface water.

\subsubsection{Holocene soil versus Pleistocene IC deposits}

As an extension of the two-end-member model, we applied a dual-carbon-isotope $\left(\delta^{13} \mathrm{C}, \Delta{ }^{14} \mathrm{C}\right)$ three-end-member model (after Karlsson et al., 2011; Vonk et al., 2010, 2012) to separate the source contributions of phytoplankton, Holocene soil and Pleistocene IC deposits (ICD) using the following equations:

$$
\begin{aligned}
& { }^{13} C_{\text {POM }}=f_{\text {soil_Holocene }} \delta^{13} C_{\text {soil }}+f_{\text {soil_ICD }} \times \delta^{13} C_{\text {soil }} \\
& +f_{\text {plankton }} \times \delta^{13} C_{\text {plankton }}, \\
& { }^{14} C_{\text {POM }}=f_{\text {soil_Holocene }}^{14} C_{\text {soil }}+f_{\text {soil_ICD }} \times{ }^{14} C_{\text {soil }} \\
& +f_{\text {plankton }} \times{ }^{14} C_{\text {plankton }}, \\
& \text { and } 1=f_{\text {soil_Holocene }}+f_{\text {soil_ICD }}+f_{\text {plankton }},
\end{aligned}
$$

where $f_{\text {soil_Holocene, }}, f_{\text {soil_ICD }}$, and $f_{\text {plankton }}$ are the fractions of Holocene soil, IC deposits, and riverine plankton contributing to each POM sample. The end-member values chosen for Holocene soil OM were $\delta^{13} \mathrm{C}-26.6 \pm 1 \%$ o and $\Delta^{14} \mathrm{C}-282 \pm 133 \%$. As the two soil end members have very similar $\delta^{13} \mathrm{C}$ values (see Table 4, Holocene soil $\delta^{13} \mathrm{C}=-26.6 \pm 1 \%$ o, IC $\delta^{13} \mathrm{C}=-26.3 \pm 0.67 \%$ ), the $\delta^{13} \mathrm{C}$ mainly determines the phytoplankton vs. total (Holocene + Pleistocene) soil fraction, whereas $\Delta^{14} \mathrm{C}$ mainly determines the fraction of Holocene to Pleistocene soil. Therefore, the results concerning the total soil fraction are very similar to those derived from the two-end-member model $\left(R^{2}=0.92\right.$, mean two-end-member soil fraction is 0.43 , mean three-endmember fraction is 0.46 , Fig. S4) than derived with the twoend-member model.

As shown in Table S5 and Fig. 4, the POM source determinations resulted in relative fractions of $0.19-0.83,0.11-0.65$, and 0.07-0.34 for plankton, Holocene soil, and IC deposits, respectively. Again, sample 31 taken off Kurungnakh Island (IC) stands out with the highest contribution from ICD (fraction of 0.34) and sample 19 taken outside the delta with highest contribution of phytoplankton (fraction of 0.83). Overall, with the end members chosen here and despite the high spatial variability within the delta, the riverine phytoplankton fraction contributes most (mean of 0.55 ) to the surface water POM compared to the Holocene soil OM (0.32) and IC deposits $(0.14)$. The rather low OM contribution from IC deposits reflects the distribution of these deposits in the Lena watershed, where they are only locally concentrated within elevations up $400 \mathrm{~m}$ (Grosse et al., 2013). 


\subsection{Implications of estimated soil-derived POM $\Delta^{14} \mathrm{C}$}

The two binary mixing models (scenario 1 and 2) discussed above allow an estimate of the soil $\Delta^{14} \mathrm{C}$ values based on a contribution of modern phytoplankton-derived OM. Both scenarios show considerably ${ }^{14} \mathrm{C}$-depleted soil-derived $\mathrm{OM}$ compared to the bulk ${ }^{14} \mathrm{C}_{\mathrm{POM}}$ concentrations. This implies that the bulk POM ${ }^{14} \mathrm{C}$ age of samples taken in surface water during the summer, when the riverine primary production is high, likely underestimate the age of the soil-derived OM transported by the Lena River. The estimated soil $\Delta^{14} \mathrm{C}$ values and ${ }^{14} \mathrm{C}$ ages in both scenarios give a more plausible picture for soil-derived POM in the Lena River watershed. In contrast to DOM, which is restricted in its flow path to the unfrozen soil layers, POM is not exclusively derived from surface soils. It also originates from resuspension of accumulated pre-aged material along the river channels and from riverbank erosion. The latter contributes POM with ${ }^{14} \mathrm{C}$ concentrations representing the whole range covered by the respective riverbank bluffs. In the Lena Delta this is predominantly $\mathrm{OM}$ of late Holocene age with local inputs from IC deposits of Pleistocene age (e.g., Bolshiyanov et al., 2015; Schirrmeister et al., 2011; Schwamborn et al., 2002). About half of the POM in the Lena Delta originates from the boreal forest hinterland south of the delta (Winterfeld et al., 2015). In the hinterland the soils along the Lena River and its tributaries can be older than the delta soils, i.e., covering the whole age range from Holocene soils to Pleistocene IC deposits (e.g., Grosse et al., 2013; Kuptsov and Lisitsin, 1996). Our estimated soil ${ }^{14} \mathrm{C}$ ages of about 2370 to 23100 years (Table 5) for both scenarios therefore better reflect these hinterland deposits contributing a heterogeneous ${ }^{14} \mathrm{C}$ age mix to riverine POM than the bulk POM ${ }^{14} \mathrm{C}$ ages.

The soil POM ${ }^{14} \mathrm{C}$ estimates as well as the Lena Delta first terrace soil data $\left(\delta^{13} \mathrm{C}\right.$ and $\left.\Delta^{14} \mathrm{C}\right)$ presented here improve our knowledge of the stable and radiocarbon isotopic range characteristic for soil-derived OM exported by the Lena River to the Laptev Sea. This information is critical for modeling the OM contribution from different terrestrial (fluvial vs. coastal erosion) and marine sources to Laptev Sea sediments and thus help in characterizing and quantifying the OM pools released from permafrost thawing. Recent studies suggest that $\mathrm{OM}$ exported by Arctic rivers and OM derived from erosion of IC coasts differ in their mineral and OM composition and thus show different potential for remineralization by microorganisms after thawing as well as different modes of transport and burial (e.g., Feng et al., 2013; Gustafsson et al., 2011; Knoblauch et al., 2013; Vonk et al., 2012). This has a direct impact on how to assess the possibility of a positive carbon-climate feedback from permafrost degradation, which has the potential to enhance global greenhouse warming by releasing huge amounts of previously frozen OM to the atmosphere.

A promising approach to distinguish OM sequestered in Arctic sediments is the dual-carbon-isotope end-member

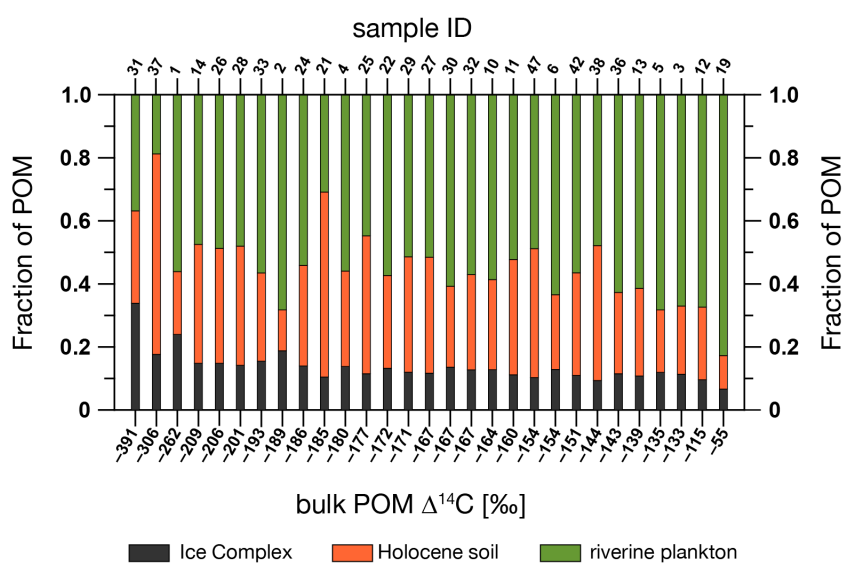

Figure 4. Results of dual-carbon-isotope $\left(\delta^{13} \mathrm{C}, \Delta^{14} \mathrm{C}\right)$ three-endmember mixing model showing the fractions for riverine phytoplankton, Holocene soils, and Pleistocene IC deposits contributing to individual surface water POM samples. The end member used in the model can be found in Table 4. Individual values comprising the Holocene soil $\delta^{13} \mathrm{C}$ and $\Delta^{14} \mathrm{C}$ end member are given in Tables S2 and S3 in the Supplement. Note that the bulk POM $\Delta^{14} \mathrm{C}$ values are ordered from the lowest to the highest and the respective sample IDs are given on the top axis.

simulation applied by Karlsson et al. (2011) and Vonk et al. $(2012,2010)$ to Laptev and East Siberian Sea sediments. The authors use the $\delta^{13} \mathrm{C}$ and $\Delta^{14} \mathrm{C}$ values of surface water suspended matter and surface sediments to quantify $\mathrm{OM}$ derived from Pleistocene IC deposits, soil/topsoil OM exported by Siberian rivers, and marine phytoplankton OM. Their end-member definitions for IC deposits and marine primary production are rather well constrained. In contrast, the soil/topsoil end member is more difficult to define, particularly when using indirect parameters such as riverine DOM and POM. Here the $\delta^{13} \mathrm{C}$ end member chosen for surface soil including our first terrace soil data (Table S2) and our estimates for soil-derived POM (Table 5) provide new $\delta^{13} \mathrm{C}$ and $\Delta^{14} \mathrm{C}$ value ranges (Fig. 3b) for fluvially exported soil POM. Together with published $\delta^{13} \mathrm{C}$ values from tundra and taiga soils in Siberia and Alaska (Bird et al., 2002; Pitkänen et al., 2002; Xu et al., 2009), we defined a Lena River soil OM end member with a $\delta^{13} \mathrm{C}$ value of $-26.6 \pm 1 \%$. Based on the $\delta^{13} \mathrm{C}$ binary mixing model (scenario 2), the corresponding $\Delta^{14} \mathrm{C}$ value is $-495 \pm 153 \%$ o (Table 5 ). We favor scenario 2 over the POC: $\mathrm{PN}$-based scenario, because it allows for the calculation of the soil fraction of each POM sample based on its bulk $\delta^{13} \mathrm{C}$ value, which is a mixture of soil and phytoplankton OM. In contrast, in the POC: PN-based scenario a constant value for particulate inorganic nitrogen is subtracted, which does not necessarily represent the actual inorganic nitrogen content of the particular sample. Moreover, it does not account for selective degradation of labile carbon, which could result in overestimating the phytoplankton contribution. 
The above-proposed $\delta^{13} \mathrm{C}$ and $\Delta^{14} \mathrm{C}$ values for the soil $\mathrm{OM}$ end member of the Lena River catchment make it more complicated to distinguish between soil/topsoil-derived OM from the river and IC deposits from coastal erosion (see Fig. 3b). The $\delta^{13} \mathrm{C}$ values of both end members are almost indistinguishable. The $\Delta^{14} \mathrm{C}$ range of our soil-derived POM estimates is lower than the end members used by Karlsson et al. (2011) and Vonk et al. (2012, 2010). Furthermore, Höfle et al. (2013) have shown that OM within the first $30 \mathrm{~cm}$ of a polygon rim of the Lena Delta first terrace can be 3000 ${ }^{14} \mathrm{C}$ years old, which makes the end members chosen for fluvial exported soil/topsoil OM by Karlsson et al. (2011) and Vonk et al. $(2012,2010)$ appear too young. Using the bulk surface water POM and DOM $\delta^{13} \mathrm{C}$ and $\Delta^{14} \mathrm{C}$ values as end members could therefore highly over- or underestimate the soil OM contribution from permafrost watersheds and in turn highly over- or underestimate OM contribution from IC to marine sediments.

However, we are aware of the limitations and uncertainties associated with the soil $\Delta^{14} \mathrm{C}$ estimates discussed above (and in Sects. 4.3.1, 4.3.2). Without determining the phytoplankton biomass of each sample by microscopic counting or from chlorophyll $a$ analysis, the plankton OM fraction calculated based on POC: $\mathrm{PN}$ ratios (Sect. 4.3.1) and $\delta^{13} \mathrm{C}$ values (Sect. 4.3.2) can only be regarded as rough estimates. These estimates give orders of magnitude of OM contribution from the individual sources rather than exact values, which in turn provide a possible range of $\Delta^{14} \mathrm{C}$ values for soil-derived POM. An additional source of uncertainty is our assumption of a modern ${ }^{14} \mathrm{C}$ concentration of plankton OM. Without determining the ${ }^{14} \mathrm{C}$ concentration of the Lena River DIC, which is utilized by phytoplankton, we cannot be sure of a modern ${ }^{14} \mathrm{C}$ concentration. Lena River DIC is derived from several sources providing carbon with different ${ }^{14} \mathrm{C}$ concentrations. DIC derived from carbonate and silicate weathering is ${ }^{14} \mathrm{C}$-depleted, DIC derived from soil respiration has a broad range of $\Delta{ }^{14} \mathrm{C}$ values due decomposition of soil OM pools of varying age, and DIC derived from exchange with the atmosphere has modern $\Delta^{14} \mathrm{C}$ values. The resulting DIC $\Delta^{14} \mathrm{C}$ value is a mixture of these sources depending on the varying contribution from each source. Furthermore, Tank et al. (2012) found that DIC yields are negatively correlated with continuous permafrost extent in the watersheds of the six largest Arctic rivers, including the Lena. This would imply that carbonate weathering is to some extent hampered by continuous permafrost making up $77 \%$ of the Lena catchment area (Tank et al., 2012). In summary, because there is no DIC $\Delta^{14} \mathrm{C}$ value available for the Lena River and there are too many factors influencing the DIC $\Delta^{14} \mathrm{C}$ value, we made the simplified assumption of a modern $\Delta^{14} \mathrm{C}$ of $41.9 \pm 4.2$ (average value of atmospheric $\mathrm{CO}_{2} \Delta^{14} \mathrm{C}$ May-August 2009-2011 from Levin et al., 2013). Consequently, if true $\Delta^{14} \mathrm{C}$ values of DIC in the Lena were depleted relative to the modern atmosphere, the soil-derived POM would be less ${ }^{14} \mathrm{C}$-depleted than estimated here. Thus,
$\Delta^{14} \mathrm{C}$ values for soils have to be considered minimum estimates or, in other words, the estimated ${ }^{14} \mathrm{C}$ soil ages have to be considered maximum ages.

The best way to determine the $\Delta^{14} \mathrm{C}$ value of riverine soil-derived $\mathrm{OM}$ would be a biomarker-specific radiocarbon analysis using source-specific compounds, e.g., shortand long-chain alkanoic acids for plankton- and terrestrialderived OM, respectively. However, for these analyses large samples of POM are needed. The samples analyzed during our study were too small to allow for compound-specific dating.

\section{Conclusions}

There are only few data available on ${ }^{14} \mathrm{C}$ concentrations of POM from Lena River surface water, but regarding the likely positive carbon-climate feedback to greenhouse warming, the quality and fate of this permafrost OM pool in the coastal waters of the Laptev Sea is currently under debate (e.g., Feng et al., 2013; Gustafsson et al., 2011; Karlsson et al., 2011; Vonk et al., 2012). With this study we provide one of the first data sets on surface water POM ${ }^{14} \mathrm{C}$ concentrations from the Lena Delta sampled during the summers of 2009 and 2010 and during spring 2011 ( $n=30$ samples). The contribution of modern phytoplankton POM to these samples was, for one, estimated using binary mixing models based on POC: $\mathrm{PN}$ ratios and $\delta^{13} \mathrm{C}$ values, which allowed us to calculate the $\Delta^{14} \mathrm{C}$ values of the soil-derived POM fraction. These soil $\Delta^{14} \mathrm{C}$ estimates were low compared to the bulk POM $\Delta^{14} \mathrm{C}$ values and therefore seem to represent the heterogeneous ${ }^{14} \mathrm{C}$ mix of soil OM ranging from Holocene to Pleistocene age (e.g., IC deposits) in the Lena River watershed more accurately. Moreover, we applied a dual-carbon-isotope three-end-member model to further distinguish between OM contributions from Holocene soils and Pleistocene IC deposits to the soil fraction. Here, we were able to show that the overall contribution of IC deposits to surface water POM in the Lena Delta was relatively low, which reflects the restricted spatial distribution of these deposits within the Lena watershed. Only samples taken close to IC deposits exhibited higher contributions of this source in the model, implying a small, locally pronounced influence on surface water POM before it becomes mixed with other soil-derived POM during fluvial transport.

Because of the limitations of our approach, particularly the assumption of modern phytoplankton OM without determining the ${ }^{14} \mathrm{C}$ concentration of the Lena River DIC utilized by phytoplankton, our ${ }^{14} \mathrm{C}$ estimates for the soil-derived fraction have to be considered minimum $\Delta^{14} \mathrm{C}$ concentrations and maximum ${ }^{14} \mathrm{C}$ ages, respectively. Nonetheless, we propose average values for the soil POM isotopic composition based on our data and published values of $\delta^{13} \mathrm{C}=-26.6 \pm 1$ and $\Delta{ }^{14} \mathrm{C}=-495 \pm 153 \%$ (Tables 5 and S2), which will be useful for dual-carbon-isotope simulations focusing on un- 
raveling the $\mathrm{OM}$ contributed by different terrigenous (fluvial vs. coastal erosion) and marine sources to Arctic sediments.

The complete data set presented here can also be found in PANGAEA (www.pangaea.de).

\section{The Supplement related to this article is available online at doi:10.5194/bg-12-3769-2015-supplement.}

Acknowledgements. The Helmholtz Young Investigators program of the Helmholtz Society (GM) and the Alfred Wegener Institute supported this study. We thank Waldemar Schneider from the Alfred Wegener Institute, Potsdam, Germany, and our Russian partners from the Tiksi Hydrobase, Lena Delta Reserve, and the Arctic and Antarctic Institute, St. Petersburg, for logistical support in preparation and during the expeditions. We acknowledge the good collaboration with the crews of the vessels Puteyski 405 and PTS during fieldwork in 2009 and 2010 and the help and good company of all participants of the LENA DELTA expeditions 2009-2011. We thank Ralph Kreutz and Peter Schreiber for taking samples in 2011 and Christiane Lorenzen (Alfred Wegener Institute, Bremerhaven, Germany) for suspended particulate organic carbon and nitrogen analysis. We further thank the two anonymous reviewers for their helpful and constructive comments, which considerably improved a previous version of this paper.

Edited by: N. Ohkouchi

\section{References}

ACIA: Impacts of a warming Arctic-Arctic Climate Impact Assessment, Cambridge, Cambridge University Press, 146 pp., 2004.

Ahad, J. M. E., Barth, J. A. C., Ganeshram, R. S., Spencer, R. G. M., and Uher, G.: Controls on carbon cycling in two contrasting temperate zone estuaries: The Tyne and Tweed, UK, Estuar. Coast. Shelf Sci., 78, 685-693, 2008.

Alling, V., Porcelli, D., Mörth, C. M., Anderson, L. G., SanchezGarcia, L., Gustafsson, Ö., Andersson, P. S., and Humborg, C.: Degradation of terrestrial organic carbon, primary production and out-gassing of CO, Geochim. Cosmochim. Ac., 95, 143-159, 2012.

Amon, R. M. W., Rinehart, A. J., Duan, S., Louchouarn, P., Prokushkin, A., Guggenberger, G., Bauch, D., Stedmon, C., Raymond, P. A., Holmes, R. M., McClelland, J. W., Peterson, B. J., Walker, S. A., and Zhulidov, A. V.: Dissolved organic matter sources in large Arctic rivers, Geochim. Cosmochim. Ac., 94, 217-237, 2012.

Bird, M. I., Santruckova, H., Arneth, A., Grigoriev, S., Gleixner, G., Kalaschnikov, Y. N., Lloyd, J., and Schulze, E. D.: Soil carbon inventories and carbon-13 on a latitude transect in Siberia, Tellus B, 54, 631-641, 2002.

Boike, J., Kattenstroth, B., Abramova, K., Bornemann, N., Chetverova, A., Fedorova, I., Fröb, K., Grigoriev, M., Grüber, M., Kutzbach, L., Langer, M., Minke, M., Muster, S., Piel, K., Pfeiffer, E.-M., Stoof, G., Westermann, S., Wischnewski, K.,
Wille, C., and Hubberten, H. W.: Baseline characteristics of climate, permafrost and land cover from a new permafrost observatory in the Lena River Delta, Siberia (1998-2011), Biogeosciences, 10, 2105-2128, doi:10.5194/bg-10-2105-2013, 2013.

Bolshiyanov, D., Makarov, A., and Savelieva, L.: Lena River delta formation during the Holocene, Biogeosciences, 12, 579-593, doi:10.5194/bg-12-579-2015, 2015.

Cauwet, G. and Sidorov, I.: The biogeochemistry of Lena River: organic carbon and nutrients distribution, Mar. Chem., 53, 211 227, 1996.

Chanton, J. and Lewis, F. G.: Examination of coupling between primary and secondary production in a river-dominated estuary: Apalachicola Bay, Florida, USA, Limnol. Oceanogr., 47, 683697, 2002.

Charkin, A., Dudarev, O., Semiletov, I., Kruhmalev, A., Vonk, J., Sanchéz-García, L., Karlsson, E., and Gustafsson, Ö.: Seasonal and interannual variability of sedimentation and organic matter distribution in the Buor-Khaya Gulf: the primary recipient of input from Lena River and coastal erosion in the southeast Laptev Sea, Biogeosciences, 8, 2581-2594, doi:10.5194/bg-82581-2011, 2011.

Dickens, A. F., Baldock, J., Kenna, T. C., and Eglinton, T. I.: A depositional history of particulate organic carbon in a floodplain lake from the lower Ob' River, Siberia, Geochim. Cosmochim. Ac., 75, 4796-4815, 2011.

Feng, X., Vonk, J. E., van Dongen, B. E., Gustafsson, Ö., Semiletov, I. P., Dudarev, O. V., Wang, Z., Montluçon, D. B., Wacker, L., and Eglinton, T. I.: Differential mobilization of terrestrial carbon pools in Eurasian Arctic river basins, P. Natl. Acad. Sci. USA, 110, 14168-14173, 2013.

Galimov, E. M., Kodina, L. A., Stepanets, O. V., and Korobeinik, G. S.: Biogeochemistry of the Russian Arctic. Kara Sea: Research results under the SIRRO project, 1995-2003, Geochem. Int., 44, 1053-1104, 2006.

Goñi, M., Yunker, M., Macdonald, R., and Eglinton, T.: Distribution and sources of organic biomarkers in arctic sediments from the Mackenzie River and Beaufort Shelf, Mar. Chem., 71, 23-51, 2000.

Goñi, M., Teixeira, M., and Perkey, D.: Sources and distribution of organic matter in a river-dominated estuary (Winyah Bay, SC, USA), Estuar. Coast. Shelf Sci., 57, 1023-1048, 2003.

Goñi, M., Yunker, M., Macdonald, R., and Eglinton, T.: The supply and preservation of ancient and modern components of organic carbon in the Canadian Beaufort Shelf of the Arctic Ocean, Mar Chem., 93, 53-73, 2005.

Gordeev, V. and Sidorov, I.: Concentrations of Major Elements and Their Outflow Into the Laptev Sea by the Lena River, Mar. Geochem., 43, 33-45. 1993.

Grigoriev, M.: Cryomorphogenesis in the Lena Delta, Permafrost Institute Press, 1993.

Grosse, G., Robinson, J. E., Bryant, R., Taylor, M. D., Harper, W., DeMasi, A., Kyker-Snowman, E., Veremeeva, A., Schirrmeister, L., and Harden, J.: Distribution of late Pleistocene ice-rich syngenetic permafrost of the Yedoma Suite in east and central Siberia, Russia, US Geological Survey Open File Report 2013 1078, p. 37, 2013.

Günther, F., Overduin, P., Sandakov, A. V., Grosse, G., and Grigoriev, M.: Short- and long-term thermo-erosion of ice-rich per- 
mafrost coasts in the Laptev Sea region, Biogeosciences, 10, 4297-4318, doi:10.5194/bg-10-4297-2013, 2013.

Guo, L. and Macdonald, R. W.: Source and transport of terrigenous organic matter in the upper Yukon River: Evidence from isotope $\left(\delta^{13} \mathrm{C}, \Delta^{14} \mathrm{C}\right.$, and $\left.\delta^{15} \mathrm{~N}\right)$ composition of dissolved, colloidal, and particulate phases, Global Biogeochem. Cy., 20, GB2011, doi:10.1029/2005GB002593, 2006.

Guo, L., Semiletov, I., Gustafsson, Ö., Ingri, J., Andersson, P., Dudarev, O., and White, D.: Characterization of Siberian Arctic coastal sediments: Implications for terrestrial organic carbon export, Global Biogeochem. Cy., 18, GB1036, doi:10.1029/2003GB002087, 2004.

Guo, L., Ping, C.-L., and Macdonald, R. W.: Mobilization pathways of organic carbon from permafrost to arctic rivers in a changing climate, Geophys. Res. Lett., 34, L13603, doi:10.1029/2007GL030689, 2007.

Gustafsson, Ö., van Dongen, B., Vonk, J., Dudarev, O., and Semiletov, I.: Widespread release of old carbon across the Siberian Arctic echoed by its large rivers, Biogeosciences, 8, 1737-1743, doi:10.5194/bg-8-1737-2011, 2011.

Hedges, J. and Oades, J.: Comparative organic geochemistries of soils and marine sediments, Org. Geochem., 27, 319-361, 1997.

Hedges, J., Keil, R., and Benner, R.: What happens to terrestrial organic matter in the ocean?, Org. Geochem., 27, 195-212, 1997.

Höfle, S., Rethemeyer, J., Mueller, C. W., and John, S.: Organic matter composition and stabilization in a polygonal tundra soil of the Lena Delta, Biogeosciences, 10, 3145-3158, doi:10.5194/bg10-3145-2013, 2013.

Holmes, R., McClelland, J., Peterson, B., Shiklomanov, I., Shiklomanov, A., Zhulidov, A., Gordeev, V., and Bobrovitskaya, N.: A circumpolar perspective on fluvial sediment flux to the Arctic Ocean, Global Biogeochem. Cy., 16, 1098, doi:10.1029/2001GB001849, 2002.

Holmes, R., McClelland, J., Peterson, B., Tank, S., Bulygina, E., Eglinton, T., Gordeev, V., Gurtovaya, T., Raymond, P., Repeta, D., Staples, R., Striegl, R., Zhulidov, A., and Zimov, S.: Seasonal and Annual Fluxes of Nutrients and Organic Matter from Large Rivers to the Arctic Ocean and Surrounding Seas, Estuar. Coast., 35, 369-382, doi:10.1007/s12237-011-9386-6, 2012.

IPCC: Climate change 2013, The physical science basis: Working group I contribution to the fifth assessment report of the IPCC, edited by: Stocker, T. F., Qin, D., Plattner, G.-K., Tignor, M. M. B., Allen, S. K., Boschung, J., Nauels, A., Xia, Y., Bex, V., and Midgley, P. M., IPCC, 1525, Cambridge University Press, Cambridge, UK and New York, USA, 5 pp., 2013.

Ivanov, V. V. and Piskun, A. A.: Distribution of river water and suspended sediment loads in the deltas of rivers in the basins of the Laptev and East-Siberian Seas, in: Land-ocean system in the Siberian Arctic, Dynamics and history, edited by: Kassens, H., Bauch, H. A., Dmitrenko, I. A., Eicken, H., Hubberten, H.-W., Melles, M., Thiede, J., and Timokhov, L. A., 239-250, Springer Berlin, Germany, 1999.

Karlsson, E., Charkin, A., Dudarev, O., Semiletov, I., Vonk, J., Sanchéz-García, L., Andersson, A., and Gustafsson, Ö.: Carbon isotopes and lipid biomarker investigation of sources, transport and degradation of terrestrial organic matter in the BuorKhaya Bay, SE Laptev Sea, Biogeosciences, 8, 1865-1879, doi:10.5194/bg-8-1865-2011, 2011.
Knoblauch, C., Beer, C., Sosnin, A., Wagner, D., and Pfeiffer, E.M.: Predicting long-term carbon mineralization and trace gas production from thawing permafrost of Northeast Siberia, Glob. Change Biol., 19, 1160-1172, 2013.

Kraberg, A. C., Druzhkova, E., Heim, B., Loeder, M. J. G., and Wiltshire, K. H.: Phytoplankton community structure in the Lena Delta (Siberia, Russia) in relation to hydrography, Biogeosciences, 10, 7263-7277, doi:10.5194/bg-10-7263-2013, 2013.

Kuhry, P. and Vitt, D.: Fossil carbon/nitrogen ratios as a measure of peat decomposition, Ecology, 77, 271-275, 1996.

Kuptsov, V. and Lisitsin, A.: Radiocarbon of quaternary along shore and bottom deposits of the Lena and the Laptev Sea sediments, Mar. Chem., 53, 301-311, 1996.

Kusch, S., Rethemeyer, J., Schefuß, E. and Mollenhauer, G.: Controls on the age of vascular plant biomarkers in Black Sea sediments, Geochim. Cosmochim. Ac., 74, 7031-7047, 2010.

Kutzbach, L., Wagner, D., and Pfeiffer, E.: Effect of microrelief and vegetation methane emission from polygonal wet tundra, Lena Delta, Northern Siberia, Biogeochemistry, 69, 341-362, 2004.

Levin, I., Kromer, B., and Hammer, S.: Atmospheric $\delta^{14} \mathrm{CO}_{2}$ end in Western European background air from 2000-2012, Tellus B, 65, 20092, doi:10.3402/tellusb.v65i0.20092, 2013.

Lisitsyn, A. P.: The marginal filter of the ocean, Oceanol. Russ. Acad. Sci., 34, 671-682, 1995.

Lobbes, J., Fitznar, H., and Kattner, G.: Biogeochemical characteristics of dissolved and particulate organic matter in Russian rivers entering the Arctic Ocean, Geochim. Cosmochim. Ac., 64, 2973-2983, 2000.

Markus, T., Stroeve, J. C., and Miller, J.: Recent changes in Arctic sea ice melt onset, freezeup, and melt season length, J. Geophys. Res., 114, C12024, doi:10.1029/2009JC005436, 2009.

McClelland, J. W., Holmes, R., Dunton, K., and Macdonald, R.: The Arctic Ocean estuary, Estuar. Coast., 35, 353-368, 2012.

McGuire, A., Anderson, L., Christensen, T., Dallimore, S., Guo, L., Hayes, D., Heimann, M., Lorenson, T., Macdonald, R., and Roulet, N.: Sensitivity of the carbon cycle in the Arctic to climate change, Ecol. Monogr., 79, 523-555, 2009.

McNichol, A. P., Osborne, E. A., Gagnon, A. R., Fry, B., and Jones, G. A.: TIC, TOC, DIC, DOC, PIC, POC-unique aspects in the preparation of oceanographic samples for 14C-AMS, Nucl. Instr. Methods Phys. R. B, 92, 162-165, 1994.

Meyers, P. A.: Preservation of Elemental and Isotopic Source Identification of Sedimentary Organic-Matter, Chem. Geol., 114, 289302, 1994.

Meyers, P. A. and Lallier-vergés, E.: Lacustrine sedimentary organic matter records of Late Quaternary paleoclimates, J. Paleolimnol., 21, 345-372, 1999.

Mook, W. G. and Tan, F. C.: Stable carbon isotopes in rivers and estuaries, in: SCOPE Report 42, Biogeochemistry of major world rivers, edited by: Degens, E. T., Kempe, S., and Richey, J., Wiley \& Sons, New York, 245-264, 1991.

Morgenstern, A., Grosse, G., and Schirrmeister, L.: Genetic, morphological, and statistical characterization of lakes in the permafrost-dominated Lena Delta, in: Proceedings of the Ninth International Conference on Permafrost, 1239-1244, 2008.

Mueller-Lupp, T., Bauch, H., Erlenkeuser, H., Hefter, J., Kassens, H., and Thiede, J.: Changes in the deposition of terrestrial organic matter on the Laptev Sea shelf during the Holocene: evi- 
dence from stable carbon isotopes, Int. J. Earth Sci., 89, 563-568, 2000 .

Neff, J., Finlay, J., Zimov, S., Davydov, S., Carrasco, J., Sschuur, E., and Davydova, A.: Seasonal changes in the age and structure of dissolved organic carbon in Siberian rivers and streams, Geophys. Res. Lett., 33, L23401, doi:10.1029/2006GL028222, 2006.

Oades, J. M.: The retention of organic matter in soils, Biogeochemistry, 5, 35-70, doi:10.1007/BF02180317, 1988.

Peterson, B., Holmes, R., McClelland, J., Vörösmarty, C., Lammers, R., Shiklomanov, A., Shiklomanov, I., and Rahmstorf, S.: Increasing river discharge to the Arctic Ocean, Science, 298, 2171-2173, 2002.

Pitkänen, A., Turunen, J., Tahvanainen, T., and Tolonen, K.: Holocene vegetation history from the Salym-Yugan Mire Area, West Siberia, The Holocene, 12, 353-362, doi:10.1191/0959683602hl533rp, 2002.

Rachold, V. and Hubberten, H.-W.: Carbon isotope composition of particulate organic material in East Siberian rivers, in: Landocean system in the Siberian Arctic. Dynamics and history, edited by: Kassens, H., Bauch, H. A., Dmitrenko, I. A., Eicken, H., Hubberten, H.-W., Melles, M., Thiede, J., and Timokhov, L. A., Springer Berlin, Germany, 223-238, 1999.

Rachold, V., Eicken, H., Gordeev, V. V., Grigoriev, M. N., Hubberten, H. W., Lisitzin, A. P., Shevchenko, V. P., and Schirrmeister, L.: Modern terrigenous organic carbon input to the Arctic Ocean, in: The organic carbon cycle in the Arctic Ocean, edited by: Stein R. and Macdonald, R. W., 33-55, 2004.

Raymond, P. and Bauer, J.: Use of ${ }^{14} \mathrm{C}$ and ${ }^{13} \mathrm{C}$ natural abundances for evaluating riverine, estuarine, and coastal DOC and POC sources and cycling: a review and synthesis, Org. Geochem., 32, 469-485, 2001.

Raymond, P., McClelland, J., Holmes, R., Zhulidov, A., Mull, K., Peterson, B., Striegl, R., Aiken, G., and Gurtovaya, T.: Flux and age of dissolved organic carbon exported to the Arctic Ocean: A carbon isotopic study of the five largest arctic rivers, Glob. Biogeochem. Cy., 21, GB4011, doi:10.1029/2007GB002934, 2007.

Sanchéz-García, L., Alling, V., Pugach, S., Vonk, J., van Dongen, B., Humborg, C., Dudarev, O., Semiletov, I., and Gustafsson, Ö.: Inventories and behavior of particulate organic carbon in the Laptev and East Siberian seas, Glob. Biogeochem. Cy., 25, GB2007, doi:10.1029/2010GB003862, 2011.

Sanders, T.: Charakterisierung Ammoniak oxidierender Mikroorganismen in Böden kalter gemäßigter Klimate und ihre Bedeutung für den globalen Stickstoffkreislauf, PhD Thesis, University of Hamburg, Hamburg, 2011.

Schirrmeister, L., Grosse, G., Wetterich, S., Overduin, P., Strauss, J., Schuur, E. A. G., and Hubberten, H. W.: Fossil organic matter characteristics in permafrost deposits of the northeast Siberian Arctic, J. Geophys. Res., 116, G00M02, doi:10.1029/2011JG001647, 2011.

Schubert, C. J. and Calvert, S. E.: Nitrogen and carbon isotopic composition of marine and terrestrial organic matter in Arctic Ocean sediments: Deep-Sea Res. Pt. I, 48, 789-810, 2001.

Schuur, E., Bockheim, J., Canadell, J., Euskirchen, E., Field, C., Goryachkin, S., Hagemann, S., Kuhry, P., Lafleur, P., Lee, H., Mazhitova, G., Nelson, F., Rinke, A., Romanovsky, V., Shiklomanov, N., Tarnocai, C., Venevsky, S., Vogel, J., and Zimov, S.: Vulnerability of permafrost carbon to climate change: Implications for the global carbon cycle, Bioscience, 58, 701-714, 2008.
Schuur, E., Vogel, J., Crummer, K., Lee, H., Sickman, J., and Osterkamp, T.: The effect of permafrost thaw on old carbon release and net carbon exchange from tundra, Nature, 459, 556-559, 2009.

Schwamborn, G., Rachold, V., and Grigoriev, M.: Late Quaternary sedimentation history of the Lena Delta, Quatern. Int., 89, 119134, 2002.

Semiletov, I., Pipko, I., Shakhova, N., Dudarev, O., Pugach, S., Charkin, A., McRoy, C., Kosmach, D., and Gustafsson, Ö.: Carbon transport by the Lena River from its headwaters to the Arctic Ocean, with emphasis on fluvial input of terrestrial particulate organic carbon vs. carbon transport by coastal erosion, Biogeosciences, 8, 2407-2426, doi:10.5194/bg-8-2407-2011, 2011.

Serreze, M. C., Walsh, J. E., Chapin, F. S., III, Osterkamp, T., Dyurgerov, M., Romanovsky, V., Oechel, W. C., Morison, J., Zhang, T., and Barry, R. G.: Observational Evidence of Recent Change in the Northern High-Latitude Environment, Clim. Change, 46, 159-207, 2000.

Sorokin, Y. I. and Sorokin, P. Y.: Plankton and primary production in the Lena River estuary and in the south-eastern Laptev Sea, Estuar. Coast. Shelf Sci., 43, 399-418, 1996.

Stuiver, M. and Polach, H.: Discussion. Reporting of 14C data, Radiocarbon, 19, 355-363, 1977.

Tank, S. E., Raymond, P. A., Striegl, R. G., McClelland, J. W., Holmes, R. M., Fiske, G. J., and Peterson, G. J.: A land-to-ocean perspective on the magnitude, source, and implication of DIC flux from major Arctic rivers to the Arctic Ocean, Glob. Biogeochem.Cy., 26, GB4018, doi:10.1029/2011GB004192, 2012.

Tarnocai, C., Canadell, J., Schuur, E., Kuhry, P., Mazhitova, G., and Zimov, S.: Soil organic carbon pools in the northern circumpolar permafrost region, Glob. Biochem. Cy., 23, GB2023, doi:10.1029/2008GB003327, 2009.

Trumbore, S.: Radiocarbon and Soil Carbon Dynamics, Annu. Rev. Earth Planet. Sci., 37, 47-66, 2009.

Trumbore, S. E.: Comparison of Carbon Dynamics in Tropical and Temperate Soils Using Radiocarbon Measurements, Glob. Biogeochem. Cy., 7, 275-290, 1993.

van Dongen, B. E., Zencak, Z., and Gustafsson, Ö.: Differential transport and degradation of bulk organic carbon and specific terrestrial biomarkers in the surface waters of a sub-arctic brackish bay mixing zone, Mar. Chem., 112, 203-214, 2008.

Vonk, J. and Gustafsson, Ö.: Calibrating n-alkane Sphagnum proxies in sub-Arctic Scandinavia, Org. Geochem., 40, 1085-1090, 2009.

Vonk, J., Sanchéz-García, L., Semiletov, I., Dudarev, O., Eglinton, T., Andersson, A., and Gustafsson, Ö.: Molecular and radiocarbon constraints on sources and degradation of terrestrial organic carbon along the Kolyma paleoriver transect, East Siberian Sea, Biogeosciences, 7, 3153-3166, doi:10.5194/bg-73153-2010, 2010.

Vonk, J. E., Sanchéz-García, L., van Dongen, B. E., Alling, V., Kosmach, D., Charkin, A., Semiletov, I. P., Dudarev, O. V., Shakhova, N., Roos, P., Eglinton, T. I., Andersson, A., and Gustafsson, Ö.: Activation of old carbon by erosion of coastal and subsea permafrost in Arctic Siberia, Nature, 489, 137-140, 2012.

Wetterich, S., Kuzmina, S., Andreev, A., Kienast, F., Meyer, H., Schirrmeister, L., Kuznetsova, T., and Sierralta, M.: Palaeoenvironmental dynamics inferred from late Quaternary permafrost 
deposits on Kurungnakh Island, Lena Delta, Northeast Siberia, Russia, Quaternary Sci. Rev., 27, 1523-1540, 2008.

Winterfeld, M., Goñi, M. A., Just, J., Hefter, J., and Mollenhauer, G.: Characterization of particulate organic matter in the Lena River delta and adjacent nearshore zone, NE Siberia - Part 2: Lignin-derived phenol compositions, Biogeosciences, 12, 22612283, doi:10.5194/bg-12-2261-2015, 2015.

Xu, C., Guo, L., Ping, C., and White, D.: Chemical and isotopic characterization of size-fractionated organic matter from cryoturbated tundra soils, northern Alaska, J. Geophys. Res., 114, G03002, doi:10.1029/2008JG000846, 2009.

Zhang, T., Frauenfeld, O., Serreze, M., Etringer, A., Oelke, C., McCreight, J., Barry, R., Gilichinsky, D., Yang, D., Ye, H., Ling, F., and Chudinova, S.: Spatial and temporal variability in active layer thickness over the Russian Arctic drainage basin, J. Geophys. Res., 110, D16101, doi:10.1029/2004JD005642, 2005.
Zimov, N., Zimov, S., Zimova, A., Zimova, G., Chuprynin, V., and Chapin, F.: Carbon storage in permafrost and soils of the mammoth tundra-steppe biome: Role in the global carbon budget, Geophys. Res. Lett., 36, L02502, doi:10.1029/2008GL036332, 2009.

Zimov, S., Schuur, E., and Chapin, F.: Permafrost and the global carbon budget, Science, 312, 1612-1613, 2006.

Zubrzycki, S.: Organic carbon pools in permafrost-affected soils of Siberian arctic regions, Ph.D, University of Hamburg, 2013.

Zubrzycki, S., Kutzbach, L., and Pfeiffer, E.: Variability of soil organic carbon stocks of different permafrost-affected soils: Initial results from a North-South transect in Siberia, Proceedings of the Tenth International Conference on Permafrost, 485-490, 2012.

Zubrzycki, S., Kutzbach, L., Grosse, G., Desyatkin, A., and Pfeiffer, E.: Organic carbon and total nitrogen stocks in soils of the Lena River Delta, Biogeosciences, 10, 3507-3524, doi:10.5194/bg10-3507-013, 2013. 